\title{
Campholenic aldehyde ozonolysis: a mechanism leading to specific biogenic secondary organic aerosol constituents
}

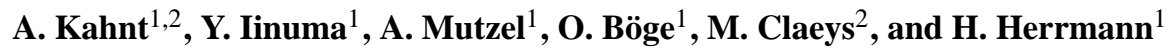 \\ ${ }^{1}$ Leibniz-Institut für Troposphärenforschung (TROPOS), Permoserstr. 15, Leipzig, 04318, Germany \\ ${ }^{2}$ Department of Pharmaceutical Sciences, University of Antwerp (Campus Drie Eiken), 2610 Antwerp, Belgium
}

Correspondence to: H. Herrmann (herrmann@ tropos.de)

Received: 1 August 2013 - Published in Atmos. Chem. Phys. Discuss.: 29 August 2013

Revised: 3 December 2013 - Accepted: 6 December 2013 - Published: 22 January 2014

\begin{abstract}
In the present study, campholenic aldehyde ozonolysis was performed to investigate pathways leading to specific biogenic secondary organic aerosol (SOA) marker compounds. Campholenic aldehyde, a known $\alpha$-pinene oxidation product, is suggested to be a key intermediate in the formation of terpenylic acid upon $\alpha$-pinene ozonolysis. It was reacted with ozone in the presence and absence of an $\mathrm{OH}$ radical scavenger, leading to SOA formation with a yield of 0.75 and 0.8 , respectively. The resulting oxidation products in the gas and particle phases were investigated employing a denuder/filter sampling combination. Gas-phase oxidation products bearing a carbonyl group, which were collected by the denuder, were derivatised by 2,4-dinitrophenylhydrazine (DNPH) followed by liquid chromatography/negative ion electrospray ionisation time-of-flight mass spectrometry analysis and were compared to the gas-phase compounds detected by online protontransfer-reaction mass spectrometry. Particle-phase products were also analysed, directly or after DNPH derivatisation, to derive information about specific compounds leading to SOA formation. Among the detected compounds, the aldehydic precursor of terpenylic acid was identified and its presence was confirmed in ambient aerosol samples from the DNPH derivatisation, accurate mass data, and additional mass spectrometry ( $\mathrm{MS}^{2}$ and $\mathrm{MS}^{3}$ fragmentation studies). Furthermore, the present investigation sheds light on a reaction pathway leading to the formation of terpenylic acid, involving $\alpha$-pinene, $\alpha$-pinene oxide, campholenic aldehyde, and terpenylic aldehyde. Additionally, the formation of diaterpenylic acid acetate could be connected to campholenic aldehyde oxidation. The present study also provides insights into the source of other highly functionalised oxidation prod-
\end{abstract}

ucts (e.g. $m / z$ 201, $\mathrm{C}_{9} \mathrm{H}_{14} \mathrm{O}_{5}$ and $m / z$ 215, $\mathrm{C}_{10} \mathrm{H}_{16} \mathrm{O}_{5}$ ), which have been observed in ambient aerosol samples and smog chamber-generated monoterpene SOA. The $m / z 201$ and 215 compounds were tentatively identified as a $C_{9}$ - and $\mathrm{C}_{10}$-carbonyl-dicarboxylic acid, respectively, based on reaction mechanisms of campholenic aldehyde and ozone, as well as detailed interpretation of mass spectral data, in conjunction with the formation of corresponding DNPH derivatives.

\section{Introduction}

Biogenic volatile organic compounds (BVOCs) are important secondary organic aerosol (SOA) precursor compounds, owing to their significant global emission and their reactivity towards atmospheric oxidants. Reactions with the $\mathrm{OH}$ radical, the nitrate radical and ozone result in multifunctional oxidation products that impact particle formation and contribute to aerosol growth. In the Northern Hemisphere where mixed and boreal forests dominate, monoterpenes such as $\alpha$ pinene, $\beta$-pinene and $\Delta^{3}$-carene are the prevailing BVOCs. In addition, other BVOCs likely serve as SOA precursors, as the observed global SOA burden cannot be explained from bottom-up approaches using laboratory-derived SOA yields from the oxidation of monoterpenes (e.g. Hallquist et al., 2009, and references therein).

Another indication for other yet unidentified and reactive BVOCs results from ozone flux measurements at boreal forest sites (Wolfe et al., 2011). Furthermore, missing sinks for OH radicals between $50 \%$ (Sinha et al., 2010) and $58 \%$ (Nölscher et al., 2012) have been reported for $\mathrm{OH}$ 
Table 1. Experimental conditions and results for the performed chamber experiments for campholenic aldehyde, $\alpha$-pinene, and $\alpha$-pinene oxide.

\begin{tabular}{|c|c|c|c|c|c|c|c|c|c|c|c|c|}
\hline Experiment & Initial HC & $\begin{array}{l}\text { Initial } \mathrm{O}_{3} \\
{[\mathrm{ppb}]}\end{array}$ & $\begin{array}{l}\mathrm{CO} \\
{[\mathrm{ppm}]}\end{array}$ & Seed particles & $\begin{array}{c}\text { Seed particle } \\
\text { pH }\end{array}$ & $\begin{array}{l}\mathrm{RH} \\
{[\%]}\end{array}$ & $\begin{array}{l}T \\
{\left[{ }^{\circ} \mathrm{C}\right]}\end{array}$ & $\begin{array}{l}\text { Reaction time } \\
\text { [min] }\end{array}$ & $\begin{array}{l}\Delta \mathrm{HC} \\
{[\mathrm{ppb}]}\end{array}$ & $\begin{array}{l}\Delta \mathrm{O}_{3} \\
{[\mathrm{ppb}]}\end{array}$ & $\begin{array}{l}\Delta \mathrm{M} \\
{\left[\mu \mathrm{g} \mathrm{m}^{-3}\right]}\end{array}$ & SOA yield \\
\hline $25 / 11 / 2010$ & $\begin{array}{l}100 \mathrm{ppb} \\
\text { campholenic } \\
\text { aldehyde }\end{array}$ & 57 & 105 & $\begin{array}{l}30 \mathrm{mM} \\
\left(\mathrm{NH}_{4}\right)_{2} \mathrm{SO}_{4} / 10 \mathrm{mM} \\
\mathrm{H}_{2} \mathrm{SO}_{4}\end{array}$ & I & 50 & 21 & 204 & 58 & 45 & 267 & 0.75 \\
\hline $26 / 11 / 2010$ & $\begin{array}{l}100 \mathrm{ppb} \\
\text { campholenic } \\
\text { aldehyde }\end{array}$ & 62 & - & $\begin{array}{l}30 \mathrm{mM} \\
\left(\mathrm{NH}_{4}\right)_{2} \mathrm{SO}_{4} / 10 \mathrm{mM} \\
\mathrm{H}_{2} \mathrm{SO}_{4}\end{array}$ & I & 50 & 21 & 204 & 68 & 45 & 342 & 0.8 \\
\hline 29/09/2010 & $\begin{array}{l}100 \mathrm{ppb} \\
\text { campholenic } \\
\text { aldehyde }\end{array}$ & 62 & - & - & - & 49 & 21 & 210 & 69 & 40 & 273 & 0.63 \\
\hline 01/03/2011 & $\begin{array}{l}100 \mathrm{ppb} \\
\alpha \text {-pinene }\end{array}$ & 60 & - & $\begin{array}{l}30 \mathrm{mM} \\
\left(\mathrm{NH}_{4}\right)_{2} \mathrm{SO}_{4} / 10 \mathrm{mM} \\
\mathrm{H}_{2} \mathrm{SO}_{4}\end{array}$ & 4 & 53 & 20 & 210 & 70 & 52 & 108 & 0.34 \\
\hline 25/02/2009 & $\begin{array}{l}100 \mathrm{ppb} \\
\alpha \text {-pinene oxide }\end{array}$ & 60 & - & $\begin{array}{l}30 \mathrm{mM} \\
\left(\mathrm{NH}_{4}\right)_{2} \mathrm{SO}_{4} \\
/ 10 \mathrm{mM} \mathrm{H}_{2} \mathrm{SO}_{4}\end{array}$ & 0 & 47 & 22 & 122 & - & - & 37.1 & - \\
\hline
\end{tabular}

reactivity measurements in boreal forests. In this context, higher molecular weight aldehydes have been suggested to be an important sink for $\mathrm{OH}$ radicals in the boreal forest (Hellén et al., 2004). For these reasons, campholenic aldehyde, a known oxidation product of $\alpha$-pinene, is an interesting candidate to be further investigated with regard to its reaction products and its SOA formation potential. The compound was first reported as an unknown $\mathrm{C}_{10} \mathrm{H}_{16} \mathrm{O}$ ketone in $\alpha$-pinene ozonolysis by Alvarado et al. (1998), and was later confirmed as campholenic aldehyde by Schrader et al. (1999). It has been reported to form from different types of oxidations, including $\alpha$-pinene reaction with $\mathrm{O}\left({ }^{3} \mathrm{P}\right)$ atoms with a yield of $0.06 \pm 0.02$ (Alvarado et al., 1998), and from $\alpha$-pinene ozonolysis in the presence of $\mathrm{NO}_{\mathrm{x}}$ with reported carbon yields in the gas and particle phases of 0.8-1.0\% (Jaoui and Kamens, 2003). Campholenic aldehyde formation was also described from the $\alpha$-pinene $\mathrm{OH}$ reaction (Van den Bergh et al., 2000, 2004), from its $\mathrm{NO}_{3}$-radical initiated oxidation (Berndt and Böge, 1997), as well as from Lewis acidcatalysed isomerisation reactions of $\alpha$-pinene oxide in the aqueous phase (Bleier and Elrod, 2013). Furthermore, campholenic aldehyde formation was recently identified during the acid-catalysed rearrangement of $\alpha$-pinene oxide, where the subsequent gas-phase ozonolysis of campholenic aldehyde could be related to a significant formation of SOA mass (Iinuma et al., 2013). The existence of campholenic aldehyde in ambient samples was reported from filter measurements (Pio et al., 2001; Anttila et al., 2005; Kallio et al., 2006); however, it is most likely also present in the gas phase owing to its high vapour pressure (Bleier and Elrod, 2013). Campholenic aldehyde has been reported as a wood odour compound (Weissbecker et al., 2004) and is also known as a natural constituent of essential oils (e.g. Gogus et al., 2006; Ali et al., 2008; Samaneh et al., 2010); hence, direct emission from plants might be possible as well.
Based on the results of a previous study (Iinuma et al., 2013), which identified campholenic aldehyde as a potentially important SOA precursor, the ozonolysis of campholenic aldehyde was further investigated in the present study. Gas- and particle-phase products were characterised in detail, thereby resorting to mass spectrometric approaches. A derivatisation technique for carbonyl group-containing compounds was applied, and the resulting derivatives were analysed by liquid chromatography coupled to high-resolution mass spectrometry (MS). Additional $\mathrm{MS}^{2}$ and $\mathrm{MS}^{3}$ fragmentation studies of specific compounds and comparison of the MS data to those of ambient filter samples were performed to derive the structures of campholenic aldehyde SOA components.

\section{Experimental}

\subsection{Chamber experiments}

Campholenic aldehyde was synthetically prepared according to the procedure by Castro et al. (2005) and was obtained in a purity of about $98 \%$, as determined by gas chromatography/mass spectrometry. Its ozonolysis was carried out in the Leipziger Aerosol Chamber (LEAK), which has a volume of $19 \mathrm{~m}^{3}$ and a $\mathrm{S} / \mathrm{V}$ ratio of $2 \mathrm{~m}^{-1}$. The polytetrafluoroethylene (PTFE) aerosol chamber is equipped to control temperature and humidity. All experiments were performed at a temperature of about $21{ }^{\circ} \mathrm{C}$ and at $50 \%$ relative humidity $(\mathrm{RH})$. Ozone was generated from a stream of oxygen $\left(5 \mathrm{~L} \mathrm{~min}^{-1}\right)$ passing an UV lamp. Initial ozone concentrations in the chamber were about $60 \mathrm{ppb}$ and were monitored during the whole experiment using an ozone monitor (Monitor Labs ML 9812). Seed particles were added to facilitate the condensation of oxidation products during the experiment. The composition of the inorganic salt solutions used, which were nebulised in the chamber, is given in Table 1 . The 
following chemicals were used to produce the inorganic seed aerosol: $\left(\mathrm{NH}_{4}\right)_{2} \mathrm{SO}_{4}\left(\geq 99 \%\right.$; Sigma-Aldrich) and $\mathrm{H}_{2} \mathrm{SO}_{4}$ (95-98\%; Sigma-Aldrich). Corresponding seed particle $\mathrm{pH}$ values for the experimental conditions (RH and $T$ ) were calculated using the extended thermodynamic E-AIM model II (Clegg et al., 1998).

The formation of secondary organic aerosol during the experiment was monitored using a differential mobility particle sizer (DMPS, 3-900 nm). A density of $1 \mathrm{~g} \mathrm{~cm}^{-3}$ was assumed to calculate the aerosol mass from the measured difference between the initial seed aerosol volume and formed organic aerosol volume during the course of the experiment. No wall loss correction was applied to the derived SOA yield data. The ozonolysis of campholenic aldehyde was performed in the presence and absence of $105 \mathrm{ppm} \mathrm{CO}$ as an $\mathrm{OH}$ radical scavenger.

The consumption of campholenic aldehyde during the ozonolysis was determined using a proton-transfer-reaction mass spectrometer (PTR-MS, IONICON Analytik, Innsbruck, Austria). For selected experiments, the PTR-MS measurements were also performed in the scan mode using an $\mathrm{m} / \mathrm{z}$ range 58-215 and a dwell time of $2 \mathrm{~s}$. These measurements made it possible to obtain additional information about gas-phase compounds which can be compared to detailed chemical information obtained from a denuder sampling technique with 2,4-dinitrophenylhydrazine (DNPH) derivatisation followed by a liquid chromatography/negative ion electrospray ionisation time-of-flight mass spectrometry (LC/(-)ESI-MS) analysis. Five-channel annular denuder tubes (URG-2000-30B5, Chapel Hill, NC, USA) were used in the present study. The inner denuder surface was coated with non-polar XAD-4 resin (Sigma-Aldrich), a divinyl styrene derivative, based on the procedure described by Kahnt et al. (2011). The derivatisation reagent DNPH was also applied on the inner denuder surface to examine oxidation products bearing carbonyl group(s). The DNPH reagent ( $\geq 99 \%$, HPLC grade) was purchased from SigmaAldrich as a $50 \%$ solution in water and was recrystallised twice in acetonitrile (HPLC grade, Sigma-Aldrich) before usage. The DNPH solution used for the denuder coating procedure consisted of $10 \mathrm{mM}$ DNPH and $90 \mathrm{mM}$ phosphoric acid (85 wt. \% in water, Riedel-de Haën) in acetonitrile. After the experiments, the denuder tubes were directly extracted using $50 \mathrm{~mL}$ acetonitrile and $1 \mathrm{~mL}$ of the internal standard (cyclohexanon-DNPH $100 \mu \mathrm{M}$ ) was added. The flask containing the denuder extract was sealed and was left overnight at room temperature to ensure complete derivatisation. After concentration by a rotary evaporator, the derivatised extract was purified using solid-phase extraction (SPE) cartridges (Oasis HLB, $30 \mathrm{mg}$ adsorbent, Waters, Milford, MA, USA). After elution from the SPE cartridge, the carbonylhydrazones were dissolved in $10 \mathrm{~mL}$ acetonitrile and stored in a freezer at $-18^{\circ} \mathrm{C}$ until analysis. This sampling preparation procedure was evaluated with various carbonyl com- pounds in a previous study and showed acceptable reproducibility and recoveries (Kahnt et al., 2011).

The simultaneously collected filter samples were also stored at $-18^{\circ} \mathrm{C}$ until further sample preparation. One half of the filters was directly extracted according to the procedure described by Iinuma et al. (2013), whereas the other half was derivatised using the DNPH reagent. For the latter derivatisation step, the cut filter pieces were immersed in a solution of $10 \mathrm{mM}$ DNPH and $1.5 \mathrm{M}$ phosphoric acid in acetonitrile. A simultaneous derivatisation and extraction was performed under ultrasonic agitation for $15 \mathrm{~min}$. The filter extract was purified by a PTFE syringe filter $(15-17 \mathrm{~mm}$ diameter, Phenomenex, Torrance, CA, USA) and the remaining filter pieces were flushed again using $500 \mu \mathrm{L}$ acetonitrile and further ultrasonication. The same SPE procedure as used for the denuder extracts was applied to the derivatised filter extracts. The solution obtained from the elution of the SPE cartridge was dried and reconstituted in $250 \mu \mathrm{L}$ acetonitrile/water $(50 / 50 \mathrm{v} / \mathrm{v})$ for LC/(-)ESI-TOFMS analysis.

\subsection{Ambient filter samples}

Ambient filter samples were analysed to confirm the relevance of selected oxidation products detected from the campholenic aldehyde $/ \mathrm{O}_{3}$ chamber experiments. The atmospheric filter samples were collected during summer 2008 at a rural background site in Seiffen, Saxony, Germany $\left(50^{\circ} 38^{\prime} 50^{\prime \prime} \mathrm{N}\right.$, $13^{\circ} 27^{\prime} 80^{\prime \prime}$ E, $647 \mathrm{~m}$ above sea level (a.s.l.)). Summer samples were chosen as a higher biogenic VOC emission was expected since a forest surrounds the village. The ambient aerosol was collected on pre-heated $\left(105^{\circ} \mathrm{C}, 24 \mathrm{~h}\right)$ quartz fibre filters (Munktell Filter AB, Falun, Sweden) using a Digitel-80 high volume sampler (Digitel Elektronik AG, Hegnau, Switzerland). The samples were collected using a $\mathrm{PM}_{10}$ inlet for a sampling duration of 24 hours (from midnight to midnight) at a flow rate of $30 \mathrm{~m}^{3} \mathrm{~h}^{-1}$. The following filter samples from Seiffen were analysed using LC/(-)ESITOFMS: 19, 27, 28 and 31 August 2008.

In addition, archived $\mathrm{PM}_{2.5}$ filter samples collected from K-puszta, Hungary $\left(46^{\circ} 58^{\prime} \mathrm{N}, 19^{\circ} 35^{\prime} \mathrm{E}, 125 \mathrm{~m}\right.$ a.s.l.) from a 2006 summer campaign were used for a further detailed mass spectrometric analysis. These ambient aerosol samples were collected during the BIOSOL (Formation mechanisms, marker compounds, and source apportionment for BIOgenic atmospheric aeroSOLs) campaign, which took place from 24 May to 29 June 2006 at K-puszta, Hungary, a rural site located on the Great Hungarian Plain, $15 \mathrm{~km}$ northwest from the nearest town Kecskemét, and $80 \mathrm{~km}$ southeast from $\mathrm{Bu}$ dapest. The surroundings of the site are dominated by mixed forest ( $62 \%$ coniferous and $28 \%$ deciduous) and grassland $(10 \%)$. The site is characterised by intensive solar radiation during summer. The composition of atmospheric particulate matter during the BIOSOL campaign was studied and it was observed that the campaign time could be divided into two periods: from the start of the campaign until 
11 June 2006 when it was unusually cold with daily maximum temperatures between 12 and $23^{\circ} \mathrm{C}$, and from 12 June 2006 onward when the temperatures were considerably higher with daily maxima ranging from 24 to $36^{\circ} \mathrm{C}$ (Maenhaut et al., 2008). Sections of quartz fibre filters from different days and/or nights of the warm period of the campaign were extracted three times for $30 \mathrm{~min}$ in an ultrasonic bath with $20 \mathrm{~mL}$ of methanol. The extracts were combined and concentrated in a rotary evaporator at $35^{\circ} \mathrm{C}$ and 200 mbar to approximately $1 \mathrm{~mL}$ and filtered through a PTFE filter $(0.45 \mu \mathrm{m})$, then evaporated to dryness under a nitrogen stream. The residue was redissolved in $1 \mathrm{~mL}$ of methanol and divided into five portions, which were dried under nitrogen, after which the residues were stored at $-20^{\circ} \mathrm{C}$ until use on different experimental days. A fraction containing $570 \mu \mathrm{g}$ of organic carbon, as determined with a thermaloptical method (Birch and Cary, 1996), was redissolved in $1.5 \mathrm{~mL}$ of methanol/water $(1 / 4, \mathrm{v} / \mathrm{v})$ by first dissolving the fraction in $0.3 \mathrm{~mL}$ of methanol and then adding $1.2 \mathrm{~mL}$ of water.

The filter samples were treated in the same manner as described for the chamber samples. For specific $\mathrm{MS}^{2}$ and $\mathrm{MS}^{3}$ fragmentation studies, $100 \mu \mathrm{L}$ of the K-puszta sample was derivatised with a $10 \mu \mathrm{L}$ DNPH solution that contained $10 \mathrm{mM}$ of the derivatisation reagent and $1.5 \mathrm{M}$ acetic acid (ULC/MS grade, Biosolve, The Netherlands) in $2.5 \mathrm{~mL}$ acetonitrile. No further sample purification using SPE was performed to minimise material loss for the chemical analysis. For these samples the analysis was carried out using LC/(-)ESI-ITMS (ion trap mass spectrometry).

\subsection{Method for the LC/(-)ESI-TOFMS analysis}

The derivatised and purified denuder and filter samples were analysed using an Agilent 1100 series HPLC system (Agilent Technologies, Santa Clara, CA, USA). The chromatographic separation of the carbonyl-hydrazones was carried out using a Pursuit XRs Ultra 2.8 Diphenyl column $(100 \times 2.0 \mathrm{~mm}$, $2.8 \mu \mathrm{m}$, Varian, Palo Alto, CA, USA) and was performed at $30^{\circ} \mathrm{C}$ with a flow rate of $0.4 \mathrm{~mL} \mathrm{~min}^{-1}$. The eluents used were (A) $1 \%$ acetic acid in Milli-Q water, (B) acetonitrile and $(\mathrm{C})$ Milli-Q water. The gradient was programmed as follows: $5 \%$ (A), $30 \%$ (B) and $65 \%$ (C) were held constant for the first $4 \mathrm{~min}$. After $20 \mathrm{~min}$, (B) was increased to $95 \%$ with $5 \%$ (A). Afterwards, (B) was further increased to $100 \%$ and was held constant for $5 \mathrm{~min}$. Then the eluents were set back to their initial conditions and held for $5 \mathrm{~min}$ to re-equilibrate the column. The system was coupled to an UV-DAD (ultraviolet diode array detector) followed by a time-of-flight (TOF) mass analyser. This setup enabled the combination of two detection modes, using UV light - as most of the carbonylhydrazones absorb light in the range of 360-380 nm, and a mass spectrometer to determine their elemental composition using TOFMS.

\subsection{High resolution fragmentation study using UPLC/(-)ESI-IMS-QTOFMS}

For a specific mono-DNPH-derivatised compound $\left(m / z\right.$ 335), the $\mathrm{MS}^{2}$ fragmentation was carried out using a TOF high-resolution mass spectrometer to elucidate its possible structure. To this end, the DNPH-derivatised filter sample was analysed using a Waters Acquity ultra performance liquid chromatography coupled to a Synapt HDMS electrospray ionisation ion mobility spectrometer and quadrupole time-of-flight mass spectrometer (UPLC/(-)ESI-IMS-QTOFMS). The chromatographic separation was carried out using an Acquity UPLC HSS T3 column $(2.1 \times 100 \mathrm{~mm}, 1.8 \mu \mathrm{m}$ particle size, Waters $)$ and the analysis was performed using an acetonitrile gradient programme as follows: $95 \%$ (A, $0.1 \%$ acetic acid in Milli-Q water) and $5 \%(\mathrm{~B}$, acetonitrile) were held constant for the first $2 \mathrm{~min}$, followed after $8 \mathrm{~min}$ by $100 \%$ (B) and held constant for $2 \mathrm{~min}$. Then the eluents were set back to their initial conditions and held for $2 \mathrm{~min}$ to re-equilibrate the column. The eluent flow rate was $0.5 \mathrm{~mL} \mathrm{~min}{ }^{-1}$ and the column temperature was kept at $40^{\circ} \mathrm{C}$. The details for the MS operating parameters can be found in Iinuma et al. (2009b).

\subsection{Method for the LC/(-)ESI-ITMS analysis for selected fragmentation studies}

Selected compounds, which were detected from the campholenic aldehyde ozonolysis, were further investigated in terms of fragmentation studies to propose possible structures. For this approach, an LC system consisting of a Surveyor Plus system (pump and autosampler) (Thermo Scientific, San Jose, CA, USA) with an Atlantis T3 column $(2.1 \times 150 \mathrm{~nm}$, $3 \mu \mathrm{m}$ particle size, Waters) was employed. The mobile phase was (A) $50 \mathrm{mM}$ ammonium formate buffer $\mathrm{pH} 3$ and (B) methanol. A 65 min gradient was applied as follows: (B) was kept at $3 \%$ for $5 \mathrm{~min}$, increased to $95 \%$ in $15 \mathrm{~min}$ and kept for $25 \mathrm{~min}$, followed by the reconditioning to $3 \%$ in $10 \mathrm{~min}$ and keeping (B) at $3 \%$ for $10 \mathrm{~min}$. The samples were injected using a volume of $10 \mu \mathrm{L}$ and the flow rate was $0.2 \mathrm{~mL} \mathrm{~min}^{-1}$. A linear ion trap mass spectrometer (LXQ, Thermo Scientific) was used as the mass analyser. The mass spectrometer was operated under the following conditions: sheath gas flow $\left(\mathrm{N}_{2}\right), 50$ arbitrary units; auxiliary gas flow $\left(\mathrm{N}_{2}\right), 5$ arbitrary units; ion source voltage $-4.5 \mathrm{kV}$; capillary temperature $350{ }^{\circ} \mathrm{C}$; and maximum ion injection time of $200 \mathrm{~ms}$. The mass spectrometer was optimised using a cis-pinonic acid standard solution, which was directly injected into the instrument at a concentration of $50 \mu \mathrm{g} \mathrm{mL}^{-1}$ together with the LC eluent mixture of ammonium formate buffer $\left(\mathrm{pH}^{3}\right)$ and methanol $(40 / 60, v / v)$. For the $\mathrm{MS}^{2}$ and $\mathrm{MS}^{3}$ experiments a target mass isolation width of $2 \mathrm{~m} / z$ units and a normalised collision energy level of $35 \%$ were applied. 
Under these conditions, the ambient filter samples (Kpuszta) and other chamber filters were analysed ( $\alpha$ pinene $/ \mathrm{O}_{3}, \alpha$-pinene oxide $/ \mathrm{O}_{3} /$ acidic seed) to compare the observed fragmentation behaviours and confirm their presence in both the laboratory-generated SOA samples and ambient samples. For the unambiguous identification of specific oxidation products, $\mathrm{MS}^{2}$ and $\mathrm{MS}^{3}$ fragmentation studies were also carried out with authentic standards. These compounds were terpenylic acid $(\mathrm{m} / \mathrm{z}$ 171) and diaterpenylic acid acetate $(m / z 231)$, which were prepared based on the procedure described by Claeys et al. (2009) and Iinuma et al. (2009a), respectively.

Detailed chamber experimental conditions for the $\alpha$ pinene $/ \mathrm{O}_{3}$ and $\alpha$-pinene oxide $/ \mathrm{O}_{3} /$ acidic seed particle studies are given in Table 1.

\section{Results and discussions}

\subsection{Aerosol formation and the effect of an $\mathrm{OH}$ radical scavenger}

All the performed ozone reactions of campholenic aldehyde resulted in SOA yields greater than 0.6, showing the high SOA formation potential of the precursor compound. A SOA yield of about 0.8 was determined in the absence of the $\mathrm{OH}$ radical scavenger $(\mathrm{CO})$, whereas in the presence of $\mathrm{CO}$ a somewhat lower SOA yield of 0.75 was observed (Fig. 1, top). It should be noted that, as no wall loss corrections were applied to the gas and particle phase data, the SOA yield data represent only lower limit values. Further studies are necessary to evaluate the wall losses for particles and vapours for this system to better estimate true SOA yield data. However, the results imply that the $\mathrm{OH}$ radical side reactions during the campholenic aldehyde ozonolysis contribute to SOA formation only to a small extent. It is interesting to note that the campholenic aldehyde ozonolysis resulted in significantly higher SOA yields in comparison to values published on $\alpha$-pinene/ $\mathrm{O}_{3}$ that range between 0.022 and 0.543 (Hoffmann et al., 1997; Griffin et al., 1999; Yu et al., 1999; Cocker et al., 2001; Presto and Donahue, 2006; Na et al., 2007; Pathak et al., 2007; Song et al., 2007; Shilling et al., 2008; Saathoff et al., 2009; Hao et al., 2011; Hatfield and Hartz, 2011; Henry and Donahue, 2011; Amin et al., 2013), which also shows the large variation and sensitivity to experimental conditions in one system. Campholenic aldehyde itself is a first-generation $\alpha$-pinene oxidation product (Fig. 2a), which is still volatile and is expected not to influence SOA growth in $\alpha$-pinene ozonolysis. Nevertheless, the present study demonstrates that campholenic aldehyde is a highly reactive compound towards ozone and an effective SOA precursor. Consequently, it is likely to be an important contributor to BSOA formation in the $\alpha$-pinene oxidation under certain conditions. The formation of campholenic aldehyde can result from different pathways, as described in the introduction; also, a di-
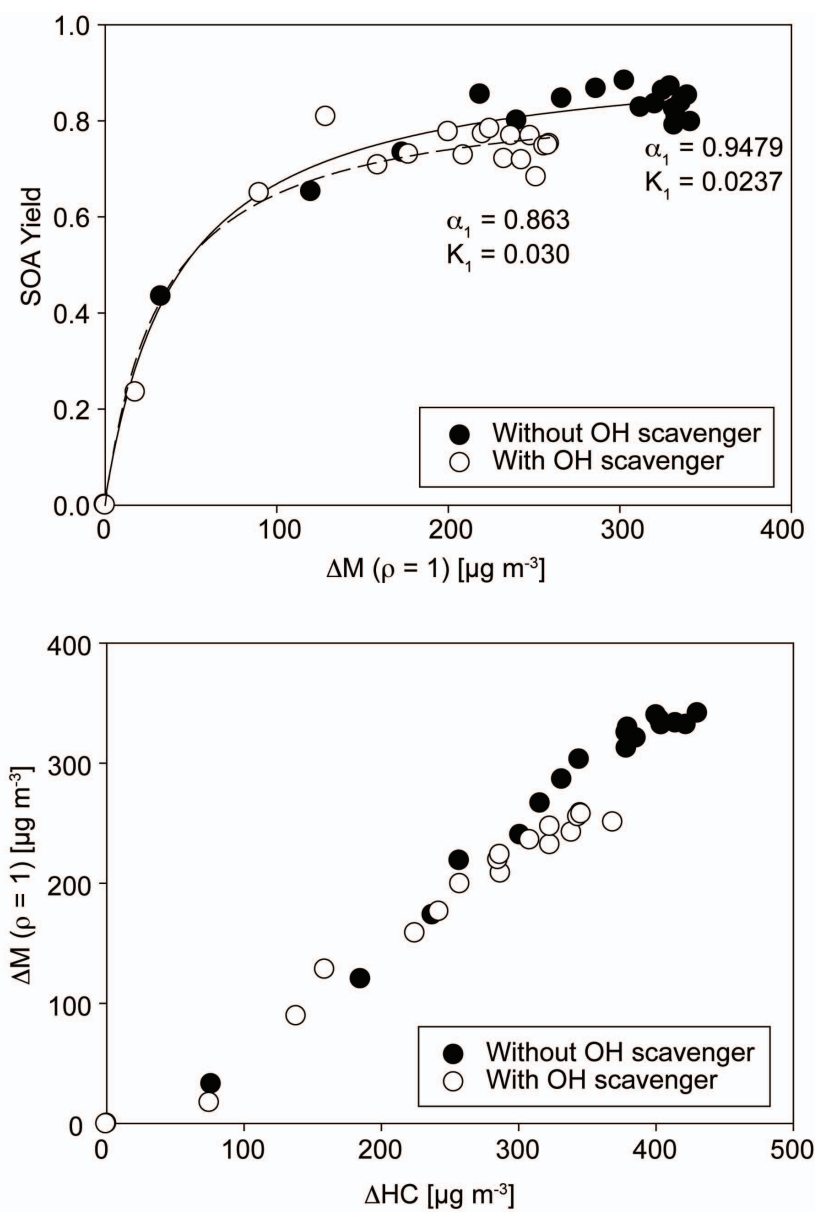

Fig. 1. SOA yield curves (top) and aerosol growth curves (bottom) for the campholenic aldehyde ozonolysis in the presence and absence of $\mathrm{CO}$ as an $\mathrm{OH}$ radical scavenger.

rect formation via not yet identified reactions, such as radical decomposition as proposed from the $\mathrm{NO}_{3}$-initiated $\alpha$-pinene oxidation (Berndt and Böge, 1997), may be involved.

In the campholenic aldehyde ozonolysis, the SOA growth curves did not change significantly with the application of $\mathrm{CO}(105 \mathrm{ppm})$ as an $\mathrm{OH}$ radical scavenger. A linear relationship between the organic mass formation and the reacted campholenic aldehyde (Fig. 1, bottom) is in line with the behaviour of other SOA precursors bearing one double bond (Ng et al., 2006). For such compounds it was concluded that the first oxidation process is rate-limiting for the aerosol formation as low-volatility products originating from the firstgeneration oxidation products contribute dominantly to SOA growth. Based on the significant amount of aerosol mass formed during the experiment, highly oxidised low-vapour pressure products were expected in the resulting SOA. In order to obtain more information about the SOA formation mechanisms in campholenic aldehyde oxidation, the resulting product distribution in both the gas and particle phases were investigated. 


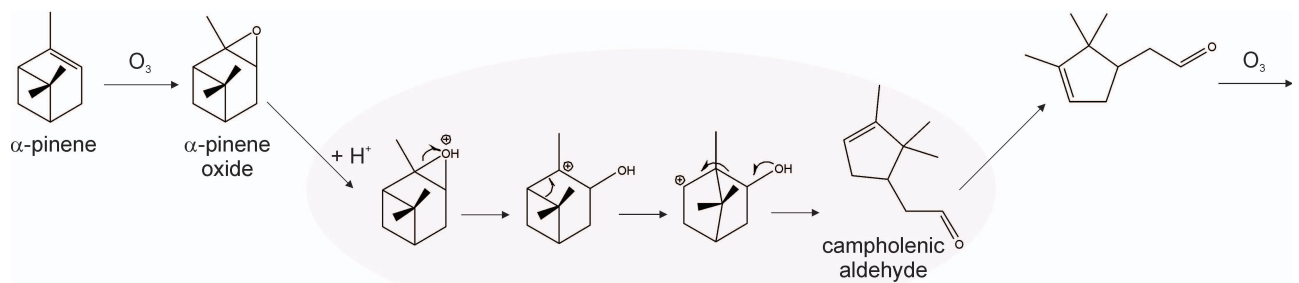

Fig. 2a. Formation of campholenic aldehyde during $\alpha$-pinene ozonolysis. The shaded area represents a particle.

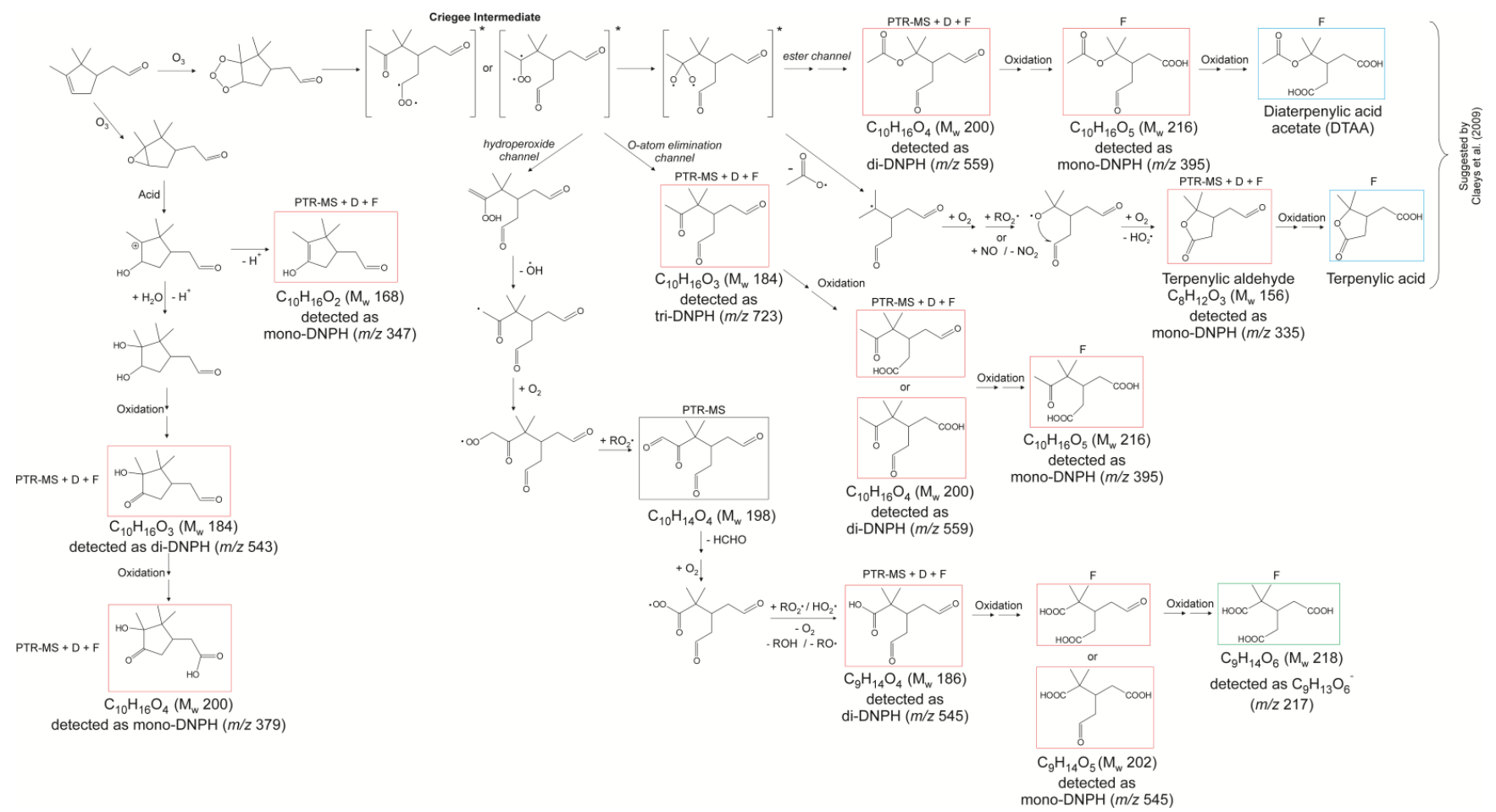

Fig. 2b. Proposed ozonolysis pathways from campholenic aldehyde leading to the detected compounds. The oxidation products identified with authentic standards are shown in blue boxes, those detected by the DNPH method are shown in red boxes, the compound shown in the black box was solely detected by PTR-MS measurements in its protonated form, and the proposed tricarboxylic acid in the green box was detected from direct filter extract analysis. (Abbreviations: $\mathrm{D}=$ detected from denuder analysis; $\mathrm{F}=$ detected from filter analysis.)

\subsection{Oxidation products detected in the gas and particle phases: $\mathrm{O}_{3}$ and $\mathrm{OH}$ reactions}

The reaction of campholenic aldehyde with ozone and possible further reactions of formed products are depicted in Fig. 2b. The first step leads to the formation of a primary ozonide resulting from the 1,3-cycloaddition of ozone to the $\mathrm{C}=\mathrm{C}$ double bond. Its decomposition leads to the excited Criegee intermediate $(\mathrm{CI})$ that reacts further, owing to its high internal energy. Different reaction channels are possible after this initial step, including an unimolecular rearrangement/decomposition of the CI or a collisional stabilisation that leads to the so-called stabilised Criegee intermediate (sCI).

Table 2 summarises the detected oxidation products in the gas phase by PTR-MS. Only a few gas-phase prod- ucts were affected by the presence or absence of the $\mathrm{OH}$ radical scavenger. The combination of PTR-MS measurements and the sampling of gaseous products using a denuder, which enabled an off-line analysis of oxidation products using LC/(-)ESI-TOFMS, led to a better characterisation of carbonyl-containing compounds compared to the use of PTR-MS alone. Based on the results obtained from TOFMS analysis, the number of hydrazone groups and hence the number of carbonyl groups in the molecule were identified (Table 3). Tentative structures were proposed based on the elemental composition and known oxidation pathways. As an unambiguous identification can only be achieved from the comparison to authentic reference compounds, the proposed structures are only tentative. 
Table 2. Summary of detected gas-phase oxidation products from the performed campholenic aldehyde experiments using PTR-MS (differences in detected products are shown in bold).

\begin{tabular}{|c|c|}
\hline Experiment & PTR-MS $[\mathrm{M}+\mathrm{H}]^{+}$ \\
\hline campholenic aldehyde $/ \mathrm{O}_{3}$ & $\begin{array}{l}59,61,71,73,75,77,81,85,87,97,99,101,113,115,123,125,127, \mathbf{1 3 7}, 139,141,143, \\
\mathbf{1 4 9}, \mathbf{1 5 1}, 155,157,165,167,169,171,173,181,183,185,187,199,201,213,215\end{array}$ \\
\hline campholenic aldehyde $/ \mathrm{O}_{3} / \mathrm{CO}$ & $\begin{array}{l}59,61, \mathbf{6 5}, 71,73,75,77,81,85,87,97,99,101, \mathbf{1 0 5}, 113,115,123,125,127, \mathbf{1 2 9}, 139, \\
141,143,155,157,165,167,169,171,173,181,183,185,187,199,201,213,215\end{array}$ \\
\hline
\end{tabular}

Table 3. Detected gas-phase compounds in the campholenic aldehyde ozonolysis using DNPH derivatisation and parallel PTR-MS measurements.

\begin{tabular}{|c|c|c|c|c|c|c|c|c|c|}
\hline $\begin{array}{c}m / z \\
\text { hydrazone } \\
{[\mathrm{M}-\mathrm{H}]^{-}} \\
\end{array}$ & $\begin{array}{l}\text { Measured } \\
\text { mass }\end{array}$ & $\begin{array}{c}\mathrm{RT} \\
{[\mathrm{min}]}\end{array}$ & $\begin{array}{c}\text { Elemental } \\
\text { composition } \\
\text { hydrazone }\end{array}$ & $\begin{array}{r}\text { Error } \\
{[\mathrm{ppm}]}\end{array}$ & $\begin{array}{c}\text { Elemental } \\
\text { composition } \\
\text { carbonyl }\end{array}$ & $\begin{array}{c}\text { Number of } \\
\text { carbonyl } \\
\text { groups }\end{array}$ & $\begin{array}{c}\mathrm{MW} \\
{\left[\mathrm{g} \mathrm{mol}^{-1}\right]}\end{array}$ & $\begin{array}{l}\text { Detected by PTR-MS } \\
\qquad[\mathrm{M}+\mathrm{H}]^{+}\end{array}$ & Suggested structure \\
\hline 335 & 335.0996 & 7.4 & $\mathrm{C}_{14} \mathrm{H}_{15} \mathrm{~N}_{4} \mathrm{O}_{6}$ & -0.2 & $\mathrm{C}_{8} \mathrm{H}_{12} \mathrm{O}_{3}$ & 1 & 156 & 157 & \\
\hline $347 \mathrm{a}$ & 347.1351 & 10.5 & $\mathrm{C}_{16} \mathrm{H}_{19} \mathrm{~N}_{4} \mathrm{O}_{5}$ & 2.8 & $\mathrm{C}_{10} \mathrm{H}_{16} \mathrm{O}_{2}$ & 1 & 168 & $\Sigma 169$ & \\
\hline $347 b$ & 347.1350 & 11.5 & $\mathrm{C}_{16} \mathrm{H}_{19} \mathrm{~N}_{4} \mathrm{O}_{5}$ & 3.2 & $\mathrm{C}_{10} \mathrm{H}_{16} \mathrm{O}_{2}$ & 1 & 168 & $\Sigma 169$ & \\
\hline 379 & 379.1249 & 12.9 & $\mathrm{C}_{16} \mathrm{H}_{19} \mathrm{~N}_{4} \mathrm{O}_{7}$ & 2.7 & $\mathrm{C}_{10} \mathrm{H}_{16} \mathrm{O}_{4}$ & 1 & 200 & $\Sigma 201$ & \\
\hline 517 & 517.1420 & 13.4 & $\mathrm{C}_{20} \mathrm{H}_{21} \mathrm{~N}_{8} \mathrm{O}_{9}$ & 3.3 & $\mathrm{C}_{8} \mathrm{H}_{14} \mathrm{O}_{3}$ & 2 & 158 & - & \\
\hline 529 & 529.1801 & 16.0 & $\mathrm{C}_{22} \mathrm{H}_{25} \mathrm{~N}_{8} \mathrm{O}_{8}$ & 1.5 & $\mathrm{C}_{10} \mathrm{H}_{18} \mathrm{O}_{2}$ & 2 & 170 & $\Sigma 171$ & \\
\hline 531 & 531.1588 & 14.4 & $\mathrm{C}_{21} \mathrm{H}_{23} \mathrm{~N}_{8} \mathrm{O}_{9}$ & 0.9 & $\mathrm{C}_{9} \mathrm{H}_{16} \mathrm{O}_{3}$ & 2 & 172 & 173 & \\
\hline 541 & 541.1419 & 12.6 & $\mathrm{C}_{22} \mathrm{H}_{21} \mathrm{~N}_{8} \mathrm{O}_{9}$ & 3.3 & $\mathrm{C}_{10} \mathrm{H}_{14} \mathrm{O}_{3}$ & 2 & 182 & 183 & \\
\hline 543 & 543.1585 & 12.7 & $\mathrm{C}_{22} \mathrm{H}_{23} \mathrm{~N}_{8} \mathrm{O}_{9}$ & 1.5 & $\mathrm{C}_{10} \mathrm{H}_{16} \mathrm{O}_{3}$ & 2 & 184 & $\Sigma 185$ & \\
\hline 545 & 545.1386 & 13.5 & $\mathrm{C}_{21} \mathrm{H}_{21} \mathrm{~N}_{8} \mathrm{O}_{10}$ & -0.2 & $\mathrm{C}_{9} \mathrm{H}_{14} \mathrm{O}_{4}$ & 2 & 186 & 187 & \\
\hline 553 & 553.1791 & 16.7 & $\mathrm{C}_{24} \mathrm{H}_{25} \mathrm{~N}_{8} \mathrm{O}_{8}$ & 1.8 & $\mathrm{C}_{12} \mathrm{H}_{18} \mathrm{O}_{2}$ & 2 & 170 & $\Sigma 171$ & \\
\hline $559 a$ & 559.1555 & 11.3 & $\mathrm{C}_{22} \mathrm{H}_{23} \mathrm{~N}_{8} \mathrm{O}_{10}$ & -2.2 & $\mathrm{C}_{10} \mathrm{H}_{16} \mathrm{O}_{4}$ & 2 & 200 & $\Sigma 201$ & \\
\hline $559 \mathrm{~b}$ & 559.1557 & 11.5 & $\mathrm{C}_{22} \mathrm{H}_{23} \mathrm{~N}_{8} \mathrm{O}_{10}$ & -2.5 & $\mathrm{C}_{10} \mathrm{H}_{16} \mathrm{O}_{4}$ & 2 & 200 & $\Sigma 201$ & \\
\hline $559 c$ & 559.1556 & 12.2 & $\mathrm{C}_{22} \mathrm{H}_{23} \mathrm{~N}_{8} \mathrm{O}_{10}$ & -2.5 & $\mathrm{C}_{10} \mathrm{H}_{16} \mathrm{O}_{4}$ & 2 & 200 & $\Sigma 201$ & or \\
\hline $559 \mathrm{~d}$ & 559.1558 & 12.7 & $\mathrm{C}_{22} \mathrm{H}_{23} \mathrm{~N}_{8} \mathrm{O}_{10}$ & -2.7 & $\mathrm{C}_{10} \mathrm{H}_{16} \mathrm{O}_{4}$ & 2 & 200 & $\Sigma 201$ & \\
\hline $559 \mathrm{e}$ & 559.1562 & 13.4 & $\mathrm{C}_{22} \mathrm{H}_{23} \mathrm{~N}_{8} \mathrm{O}_{10}$ & -3.4 & $\mathrm{C}_{10} \mathrm{H}_{16} \mathrm{O}_{4}$ & 2 & 200 & $\Sigma 201$ & \\
\hline 723 & 723.1807 & 16.4 & $\mathrm{C}_{28} \mathrm{H}_{27} \mathrm{~N}_{12} \mathrm{O}_{12}$ & 9.7 & $\mathrm{C}_{10} \mathrm{H}_{16} \mathrm{O}_{3}$ & 3 & 184 & $\Sigma 185$ & \\
\hline
\end{tabular}

The LC/MS analysis of the DNPH-derivatised denuder extracts showed only a marginal difference in the product distribution between the campholenic aldehyde $/ \mathrm{O}_{3}$ and campholenic aldehyde $/ \mathrm{O}_{3} / \mathrm{CO}$ experiments. In addition, the product distribution from the filter analysis revealed no differences between the two types of experiments for both the direct filter extract analysis and the method using the DNPH derivatisation. This indicates that the SOA-forming compounds are mainly formed from the reaction of campholenic aldehyde with ozone while the $\mathrm{OH}$ radical side reaction in the ozonolysis experiments only contributes to a minor extent to product formation and associated SOA increase. This is in line with the results obtained from the SOA growth behaviour as described in the previous section.

\subsection{Individual compounds}

For compounds that were observed both from the campholenic aldehyde ozonolysis SOA and the ambient filter, further efforts were done to derive structural information. A summary of oxidation products in the filter samples that could be detected as DNPH derivatives is given in Table 4, together with their elemental composition and tentative structures.

For selected compounds also $\mathrm{MS}^{2}$ and $\mathrm{MS}^{3}$ studies were performed and an overview of the performed experiments is provided in Table 5. The individual product ion spectra are shown in the Supplement but selected oxidation products will be discussed in this section. 
Table 4. Detected particle-phase compounds in the campholenic aldehyde ozonolysis using DNPH derivatisation.

\begin{tabular}{|c|c|c|c|c|c|c|c|c|}
\hline $\begin{array}{c}m / z \\
\text { hydrazone } \\
{[\mathrm{M}-\mathrm{H}]^{-}}\end{array}$ & $\begin{array}{l}\text { Measured } \\
\text { mass }\end{array}$ & $\begin{array}{l}\text { RT } \\
{[\mathrm{min}]}\end{array}$ & $\begin{array}{l}\text { Elemental } \\
\text { composition } \\
\text { hydrazone }\end{array}$ & $\begin{array}{l}\text { Error } \\
\text { [ppm] }\end{array}$ & $\begin{array}{c}\text { Elemental } \\
\text { composition } \\
\text { carbonyl }\end{array}$ & $\begin{array}{l}\text { Number of } \\
\text { carbonyl } \\
\text { groups }\end{array}$ & $\begin{array}{c}\mathrm{MW} \\
{\left[\mathrm{g} \mathrm{mol}^{-1}\right]}\end{array}$ & $\begin{array}{c}\text { Suggested } \\
\text { structure }\end{array}$ \\
\hline 335 & 335.0974 & 7.6 & $\mathrm{C}_{14} \mathrm{H}_{15} \mathrm{~N}_{4} \mathrm{O}_{6}$ & 7.0 & $\mathrm{C}_{8} \mathrm{H}_{12} \mathrm{O}_{3}$ & 1 & 156 & \\
\hline 347 & 347.1337 & 11.5 & $\mathrm{C}_{16} \mathrm{H}_{19} \mathrm{~N}_{4} \mathrm{O}_{5}$ & 7.0 & $\mathrm{C}_{10} \mathrm{H}_{16} \mathrm{O}_{2}$ & 1 & 168 & \\
\hline 379 & 379.1249 & 2.7 & $\mathrm{C}_{16} \mathrm{H}_{19} \mathrm{~N}_{4} \mathrm{O}_{7}$ & 2.6 & $\mathrm{C}_{10} \mathrm{H}_{16} \mathrm{O}_{4}$ & 1 & 200 & \\
\hline $381 \mathrm{a}$ & 381.1043 & 2.4 & $\mathrm{C}_{15} \mathrm{H}_{17} \mathrm{~N}_{4} \mathrm{O}_{8}$ & 2.4 & $\mathrm{C}_{9} \mathrm{H}_{14} \mathrm{O}_{5}$ & 1 & 202 & \\
\hline $381 b$ & 381.1036 & 3.5 & $\mathrm{C}_{15} \mathrm{H}_{17} \mathrm{~N}_{4} \mathrm{O}_{8}$ & 4.2 & $\mathrm{C}_{9} \mathrm{H}_{14} \mathrm{O}_{5}$ & 1 & 202 & \\
\hline $381 \mathrm{c}$ & 381.1033 & 4.4 & $\mathrm{C}_{15} \mathrm{H}_{17} \mathrm{~N}_{4} \mathrm{O}_{8}$ & 4.8 & $\mathrm{C}_{9} \mathrm{H}_{14} \mathrm{O}_{5}$ & 1 & 202 & or \\
\hline 395 & 395.1195 & 4.6 & $\mathrm{C}_{16} \mathrm{H}_{19} \mathrm{~N}_{4} \mathrm{O}_{8}$ & 3.3 & $\mathrm{C}_{10} \mathrm{H}_{16} \mathrm{O}_{5}$ & 1 & 216 & \\
\hline $409 a$ & 409.0997 & 2.6 & $\mathrm{C}_{16} \mathrm{H}_{17} \mathrm{~N}_{4} \mathrm{O}_{9}$ & 1.0 & $\mathrm{C}_{10} \mathrm{H}_{14} \mathrm{O}_{6}$ & 1 & 230 & \\
\hline $409 b$ & 409.0991 & 3.0 & $\mathrm{C}_{16} \mathrm{H}_{17} \mathrm{~N}_{4} \mathrm{O}_{9}$ & 2.5 & $\mathrm{C}_{10} \mathrm{H}_{14} \mathrm{O}_{6}$ & 1 & 230 & \\
\hline $409 c$ & 409.0989 & 3.6 & $\mathrm{C}_{16} \mathrm{H}_{17} \mathrm{~N}_{4} \mathrm{O}_{9}$ & 2.9 & $\mathrm{C}_{10} \mathrm{H}_{14} \mathrm{O}_{6}$ & 1 & 230 & \\
\hline $409 d$ & 409.0995 & 4.3 & $\mathrm{C}_{16} \mathrm{H}_{17} \mathrm{~N}_{4} \mathrm{O}_{9}$ & 1.4 & $\mathrm{C}_{10} \mathrm{H}_{14} \mathrm{O}_{6}$ & 1 & 230 & \\
\hline 541 & 541.1416 & 12.7 & $\mathrm{C}_{22} \mathrm{H}_{21} \mathrm{~N}_{8} \mathrm{O}_{9}$ & 3.9 & $\mathrm{C}_{10} \mathrm{H}_{14} \mathrm{O}_{3}$ & 2 & 182 & \\
\hline $543 a$ & 543.1550 & 12.7 & $\mathrm{C}_{22} \mathrm{H}_{23} \mathrm{~N}_{8} \mathrm{O}_{9}$ & 8.1 & $\mathrm{C}_{10} \mathrm{H}_{16} \mathrm{O}_{3}$ & 2 & 184 & \\
\hline $543 \mathrm{c}$ & 543.1567 & 14.9 & $\mathrm{C}_{22} \mathrm{H}_{23} \mathrm{~N}_{8} \mathrm{O}_{9}$ & 4.9 & $\mathrm{C}_{10} \mathrm{H}_{16} \mathrm{O}_{3}$ & 2 & 184 & \\
\hline $543 d$ & 543.1568 & 15.4 & $\mathrm{C}_{22} \mathrm{H}_{23} \mathrm{~N}_{8} \mathrm{O}_{9}$ & 4.7 & $\mathrm{C}_{10} \mathrm{H}_{16} \mathrm{O}_{3}$ & 2 & 184 & \\
\hline $543 b$ & 543.1210 & 14.2 & $\mathrm{C}_{21} \mathrm{H}_{19} \mathrm{~N}_{8} \mathrm{O}_{10}$ & 3.6 & $\mathrm{C}_{9} \mathrm{H}_{12} \mathrm{O}_{4}$ & 2 & 184 & \\
\hline $545 \mathrm{a}$ & 545.1358 & 9.2 & $\mathrm{C}_{21} \mathrm{H}_{21} \mathrm{~N}_{8} \mathrm{O}_{10}$ & 5.1 & $\mathrm{C}_{9} \mathrm{H}_{14} \mathrm{O}_{4}$ & 2 & 186 & \\
\hline
\end{tabular}

\subsubsection{MW 184 compound (detected as tri-DNPH derivative $m / z$ 723)}

A tri-carbonyl compound with an elemental composition of $\mathrm{C}_{10} \mathrm{H}_{16} \mathrm{O}_{3}$ and an $m / z$ value of 723 for the tri-DNPH derivative and of 183 for the non-derivatised compound was de- tected from both the denuder and filter samples. This compound can be explained via the $\mathrm{O}$-atom elimination channel from the $\mathrm{CI}$ and represents a first-generation oxidation product in the campholenic aldehyde ozonolysis (Fig. 2b). It is likely to partition into the particle phase as well, where further oxidation is expected to lead to even more functionalised 
Table 4. Continued.

\begin{tabular}{|c|c|c|c|c|c|c|c|c|}
\hline $\begin{array}{c}m / z \\
\text { hydrazone } \\
{[\mathrm{M}-\mathrm{H}]^{-}}\end{array}$ & $\begin{array}{c}\text { Measured } \\
\text { mass }\end{array}$ & $\begin{array}{c}\mathrm{RT} \\
{[\mathrm{min}]}\end{array}$ & $\begin{array}{l}\text { Elemental } \\
\text { composition } \\
\text { hydrazone }\end{array}$ & $\begin{array}{l}\text { Error } \\
{[\mathrm{ppm}]}\end{array}$ & $\begin{array}{l}\text { Elemental } \\
\text { composition } \\
\text { carbonyl }\end{array}$ & $\begin{array}{c}\text { Number of } \\
\text { carbonyl } \\
\text { groups }\end{array}$ & $\begin{array}{c}\mathrm{MW} \\
{\left[\mathrm{g} \mathrm{mol}^{-1}\right]}\end{array}$ & $\begin{array}{c}\text { Suggested } \\
\text { structure }\end{array}$ \\
\hline $545 \mathrm{~b}$ & 545.1352 & 9.8 & $\mathrm{C}_{21} \mathrm{H}_{21} \mathrm{~N}_{8} \mathrm{O}_{10}$ & 6.3 & $\mathrm{C}_{9} \mathrm{H}_{14} \mathrm{O}_{4}$ & 2 & 186 & \\
\hline $545 \mathrm{c}$ & 545.1376 & 11.4 & $\mathrm{C}_{21} \mathrm{H}_{21} \mathrm{~N}_{8} \mathrm{O}_{10}$ & 1.9 & $\mathrm{C}_{9} \mathrm{H}_{14} \mathrm{O}_{4}$ & 2 & 186 & \\
\hline $545 \mathrm{~d}$ & 545.1430 & 12.0 & $\mathrm{C}_{21} \mathrm{H}_{21} \mathrm{~N}_{8} \mathrm{O}_{10}$ & -11 & $\mathrm{C}_{9} \mathrm{H}_{14} \mathrm{O}_{4}$ & 2 & 186 & \\
\hline $545 \mathrm{e}$ & 545.1356 & 12.5 & $\mathrm{C}_{21} \mathrm{H}_{21} \mathrm{~N}_{8} \mathrm{O}_{10}$ & 5.6 & $\mathrm{C}_{9} \mathrm{H}_{14} \mathrm{O}_{4}$ & 2 & 186 & \\
\hline $545 \mathrm{f}$ & 545.1364 & 13.1 & $\mathrm{C}_{21} \mathrm{H}_{21} \mathrm{~N}_{8} \mathrm{O}_{10}$ & 4.0 & $\mathrm{C}_{9} \mathrm{H}_{14} \mathrm{O}_{4}$ & 2 & 186 & \\
\hline $545 \mathrm{~g}$ & 545.1403 & 13.5 & $\mathrm{C}_{21} \mathrm{H}_{21} \mathrm{~N}_{8} \mathrm{O}_{10}$ & -3.1 & $\mathrm{C}_{9} \mathrm{H}_{14} \mathrm{O}_{4}$ & 2 & 186 & \\
\hline 557 & 557.1383 & 11.7 & $\mathrm{C}_{22} \mathrm{H}_{21} \mathrm{~N}_{8} \mathrm{O}_{10}$ & 0.5 & $\mathrm{C}_{10} \mathrm{H}_{14} \mathrm{O}_{4}$ & 2 & 198 & \\
\hline $559 \mathrm{a}$ & 559.1552 & 9.1 & $\mathrm{C}_{22} \mathrm{H}_{23} \mathrm{~N}_{8} \mathrm{O}_{10}$ & -1.7 & $\mathrm{C}_{10} \mathrm{H}_{16} \mathrm{O}_{4}$ & 2 & 200 & \\
\hline $559 \mathrm{~b}$ & 559.1526 & 11.3 & $\mathrm{C}_{22} \mathrm{H}_{23} \mathrm{~N}_{8} \mathrm{O}_{10}$ & 3.1 & $\mathrm{C}_{10} \mathrm{H}_{16} \mathrm{O}_{4}$ & 2 & 200 & \\
\hline $559 \mathrm{c}$ & 559.1537 & 11.5 & $\mathrm{C}_{22} \mathrm{H}_{23} \mathrm{~N}_{8} \mathrm{O}_{10}$ & 1.0 & $\mathrm{C}_{10} \mathrm{H}_{16} \mathrm{O}_{4}$ & 2 & 200 & or \\
\hline $559 \mathrm{~d}$ & 559.1557 & 12.0 & $\mathrm{C}_{22} \mathrm{H}_{23} \mathrm{~N}_{8} \mathrm{O}_{10}$ & -2.5 & $\mathrm{C}_{10} \mathrm{H}_{16} \mathrm{O}_{4}$ & 2 & 200 & \\
\hline $559 \mathrm{e}$ & 559.1541 & 12.3 & $\mathrm{C}_{22} \mathrm{H}_{23} \mathrm{~N}_{8} \mathrm{O}_{10}$ & 0.3 & $\mathrm{C}_{10} \mathrm{H}_{16} \mathrm{O}_{4}$ & 2 & 200 & \\
\hline $559 \mathrm{f}$ & 559.1542 & 12.7 & $\mathrm{C}_{22} \mathrm{H}_{23} \mathrm{~N}_{8} \mathrm{O}_{10}$ & 0.1 & $\mathrm{C}_{10} \mathrm{H}_{16} \mathrm{O}_{4}$ & 2 & 200 & \\
\hline $559 \mathrm{~g}$ & 559.1534 & 13.4 & $\mathrm{C}_{22} \mathrm{H}_{23} \mathrm{~N}_{8} \mathrm{O}_{10}$ & 1.5 & $\mathrm{C}_{10} \mathrm{H}_{16} \mathrm{O}_{4}$ & 2 & 200 & \\
\hline $573 a$ & 573.1311 & 11.2 & $\mathrm{C}_{22} \mathrm{H}_{21} \mathrm{~N}_{8} \mathrm{O}_{11}$ & 4.3 & $\mathrm{C}_{10} \mathrm{H}_{14} \mathrm{O}_{5}$ & 2 & 214 & \\
\hline $573 b$ & 573.1305 & 12.4 & $\mathrm{C}_{22} \mathrm{H}_{21} \mathrm{~N}_{8} \mathrm{O}_{11}$ & 5.2 & $\mathrm{C}_{10} \mathrm{H}_{14} \mathrm{O}_{5}$ & 2 & 214 & \\
\hline 589 & 589.1293 & 12.0 & $\mathrm{C}_{22} \mathrm{H}_{21} \mathrm{~N}_{8} \mathrm{O}_{12}$ & -0.3 & $\mathrm{C}_{10} \mathrm{H}_{14} \mathrm{O}_{6}$ & 2 & 230 & \\
\hline
\end{tabular}

products. Such functionalised species were indeed detected in the filter samples at $m / z 171,187,199,201,215,229$, and 231. Considering these highly functionalised species, the proposed tri-carbonyl compound $\left(\mathrm{C}_{10} \mathrm{H}_{16} \mathrm{O}_{3}, \mathrm{~m} / \mathrm{z}\right.$ 183) might constitute an intermediate during the formation of the latter functionalised species in later oxidation steps.

\subsubsection{Terpenylic acid (MW 172) and diaterpenylic acid acetate (MW 232)}

As shown in Fig. 2b, the formation of terpenylic acid and diaterpenylic acid acetate (DTAA) has been suggested to proceed from the further reaction of campholenic aldehyde, which can be formed during the $\alpha$-pinene ozonolysis from $\alpha$ pinene oxide (Claeys et al., 2009; Iinuma et al., 2013). The comparison of filter samples from campholenic aldehyde $/ \mathrm{O}_{3}$, $\alpha$-pinene oxide $/ \mathrm{O}_{3} /$ acidic seed particles, $\alpha$-pinene $/ \mathrm{O}_{3}$ chamber experiments and ambient aerosol samples confirmed the proposed pathway as both terpenylic acid $(m / z 171)$ and DTAA $(m / z 231)$ could be unambiguously identified in all of the investigated filter samples (Figs. S2 and S24). This confirmation was based on matching retention times ( $R T \mathrm{~s})$ and the same mass spectral fragmentation behaviour as those of authentic standard compounds. As the identification of terpenylic acid from campholenic aldehyde ozonolysis has recently been discussed by Iinuma et al. (2013), only the $\mathrm{MS}^{2}$ and $\mathrm{MS}^{3}$ data from the compound that was unambiguously identified as DTAA are shown in Fig. 3. The additional $\mathrm{m} / \mathrm{z} 231$ compound eluting at $22.4 \mathrm{~min}$ is not identified at the present stage, but its fragmentation is shown in the Supplement related to this article (Fig. S25; see URL at end). Based on the results obtained in the present study, valuable information about chemical formation pathways of important BSOA constituents could be obtained.

\subsubsection{MW 156 compound (detected as mono-DNPH derivative $m / z$ 335)}

Both the denuder and filter samples showed the presence of a mono-DNPH derivative at $m / z$ 335. This oxidation product was also observed in $\alpha$-pinene ozonolysis samples and in ambient filter samples collected in Seiffen, Germany (Fig. 4). Due to its atmospheric relevance further efforts were made to characterise the $m / z, 335$ compound. MS $^{2}$ experiments with a high-resolution mass spectrometer enabled the determination of the elemental composition of certain product ions (Fig. 5). The product ions at $m / z$ 179, 163, 152 and 120 are commonly observed DNPH fragments and have been described in the literature (Brombacher et al., 2001; Kölliker et al., 2001). As can be seen in Fig. 5, the $\mathrm{MS}^{2}$ product ion spectrum is dominated by DNPH-related product ions though other specific ions could also be observed. Among those, the $\mathrm{m} / \mathrm{z} 171$ was the most abundant product ion and, therefore, it was further investigated by additional $\mathrm{MS}^{3}$ experiments using ion trap mass spectrometry (ITMS). For these $\mathrm{MS}^{n}$ studies the filter samples were freshly 
Table 5. List of products with matching $R T$ observed from campholenic aldehyde $/ \mathrm{O}_{3}, \alpha$-pinene oxide $/ \mathrm{O}_{3} /$ acidic seed, $\alpha$-pinene $/ \mathrm{O}_{3}$ and a K-puszta filter sample, including their corresponding DNPH derivatives (when appropriate). The table summarises all the mass spectral data recorded in the present study.

\begin{tabular}{|c|c|c|c|c|c|c|}
\hline$m / z[\mathrm{M}-\mathrm{H}]^{-}$ & Elemental composition & $R T(\min )$ & $\begin{array}{l}\text { Product ion } \\
\text { spectra }\end{array}$ & $\begin{array}{l}\text { Corresponding DNPH } \\
\text { derivative } m / z[\mathrm{M}-\mathrm{H}]^{-}\end{array}$ & $R T(\min )$ & $\begin{array}{l}\text { Product ion } \\
\text { spectra }\end{array}$ \\
\hline- & $\mathrm{C}_{8} \mathrm{H}_{12} \mathrm{O}_{3}$ & & & 335 (mono-DNPH) & 27.3 & $\begin{array}{l}\text { MS }^{2} 335 ; \\
\text { MS }^{3} 335 \rightarrow 171\end{array}$ \\
\hline 171 & terpenylic acid & 19.1 & $\begin{array}{l}\mathrm{MS}^{2} 171 \\
\mathrm{MS}^{3} 171 \rightarrow 127\end{array}$ & - & & \\
\hline \multirow[t]{3}{*}{187} & $\mathrm{C}_{8} \mathrm{H}_{12} \mathrm{O}_{5}$ & 16.9 & $\begin{array}{l}\mathrm{MS}^{2} 187 \\
\mathrm{MS}^{3} 187 \rightarrow 125\end{array}$ & & & \\
\hline & & 17.7 & $\begin{array}{l}\mathrm{MS}^{2} 187 \\
\mathrm{MS}^{3} 187 \rightarrow 125\end{array}$ & & & \\
\hline & & 19.5 & $\begin{array}{l}\mathrm{MS}^{2} 187 \\
\mathrm{MS}^{3} 187 \rightarrow 143\end{array}$ & & & \\
\hline \multirow[t]{2}{*}{199} & $\mathrm{C}_{10} \mathrm{H}_{16} \mathrm{O}_{4}$ & 20.8 & $\begin{array}{l}\mathrm{MS}^{2} 199 ; \\
\mathrm{MS}^{3} 199 \rightarrow 181\end{array}$ & 379 (mono-DNPH) & 27.1 & $\mathrm{MS}^{2} 379$ \\
\hline & & $22^{\mathrm{a}}$ & $\begin{array}{l}\mathrm{MS}^{2} 199 ; \\
\mathrm{MS}^{3} 199 \rightarrow 181\end{array}$ & 559 (di-DNPH) & 28.4 & $\mathrm{MS}^{2} 559$ \\
\hline 201 & $\mathrm{C}_{9} \mathrm{H}_{14} \mathrm{O}_{5}$ & 20.8 & $\begin{array}{l}\mathrm{MS}^{2} 201 ; \\
\text { MS }^{3} 201 \rightarrow 157\end{array}$ & 381 (mono-DNPH) & 27.4 & $\mathrm{MS}^{2} 381$ \\
\hline 215 & $\mathrm{C}_{10} \mathrm{H}_{16} \mathrm{O}_{5}$ & 21.1 & $\begin{array}{l}\mathrm{MS}^{2} 215 ; \\
\mathrm{MS}^{3} 215 \rightarrow 171\end{array}$ & 395 (mono-DNPH) & 28.2 & $\mathrm{MS}^{2} 395$ \\
\hline \multirow[t]{2}{*}{229} & $\mathrm{C}_{10} \mathrm{H}_{14} \mathrm{O}_{6}$ & 20.0 & $\begin{array}{l}\mathrm{MS}^{2} 229 ; \\
\mathrm{MS}^{3} 229 \rightarrow 185\end{array}$ & 409 (mono-DNPH) & $\begin{array}{l}25.4^{\mathrm{b}} \\
25.8^{\mathrm{b}}\end{array}$ & $\mathrm{MS}^{2} 409$ \\
\hline & & & & 589 (di-DNPH) & $24.0^{\mathrm{b}}$ & $\mathrm{MS}^{2} 589$ \\
\hline \multirow[t]{2}{*}{231} & DTAA $^{c}$ & 22 & $\begin{array}{l}\operatorname{MS}^{2} 231 ; \\
\text { MS }^{3} 231 \rightarrow 171\end{array}$ & - & & \\
\hline & $\mathrm{C}_{10} \mathrm{H}_{16} \mathrm{O}_{6}$ & 22.4 & $\begin{array}{l}\text { MS }^{2} 231 ; \\
\text { MS }^{3} 231 \rightarrow 199\end{array}$ & & & \\
\hline
\end{tabular}

a only detected in campholenic aldehyde/ $\mathrm{O}_{3}$ and the ambient SOA sample;

$\mathrm{b}$ in campholenic aldehyde $/ \mathrm{O}_{3}$ and $\alpha$-pinene oxide $/ \mathrm{O}_{3} /$ acidic seed;

c DTAA = diaterpenylic acid acetate.
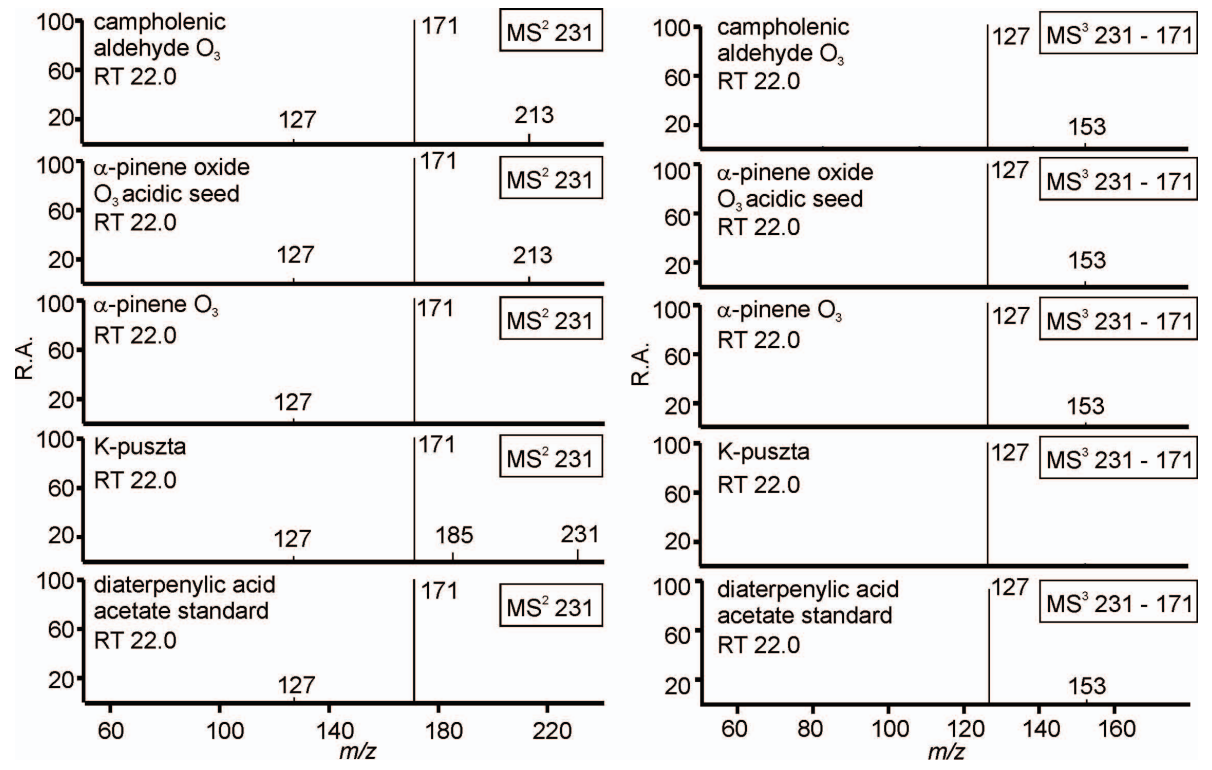

Fig. 3. $\mathrm{MS}^{2}$ and $\mathrm{MS}^{3}$ product ion spectra for the $m / z 231$ compound ( $R T 22 \mathrm{~min}$ ) unambiguously identified as DTAA. 


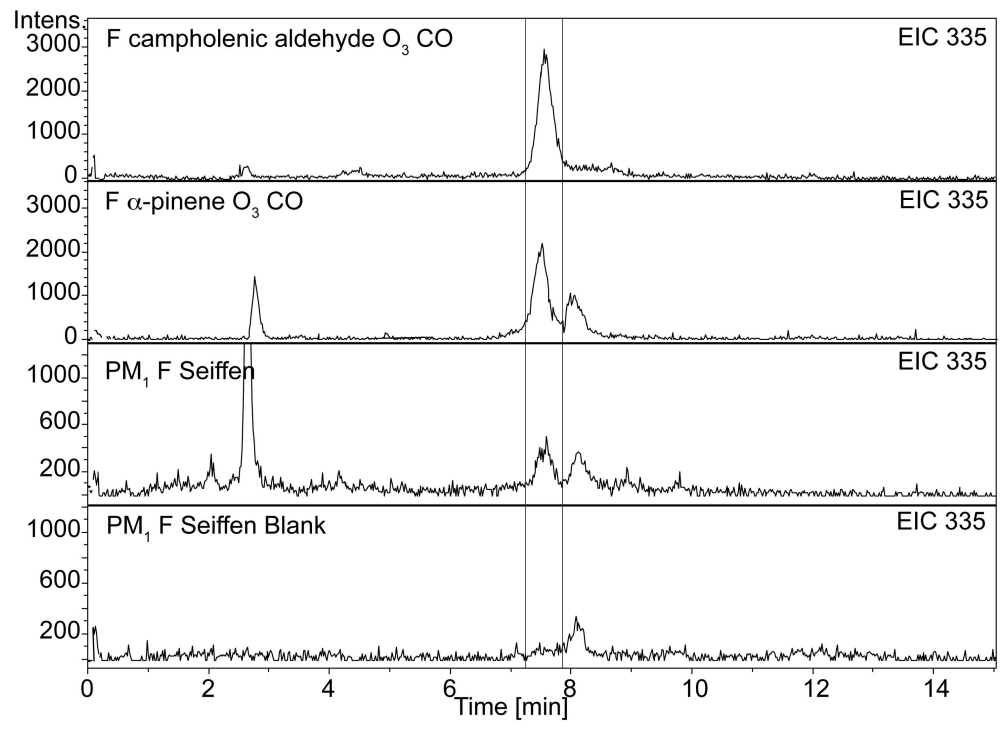

Fig. 4. Extracted ion chromatograms (EICs) of a mono-DNPH-derivatised compound $(\mathrm{m} / \mathrm{z}$ 335) detected in campholenic aldehyde ozonolysis, $\alpha$-pinene ozonolysis and an ambient filter sample (Seiffen, Germany).

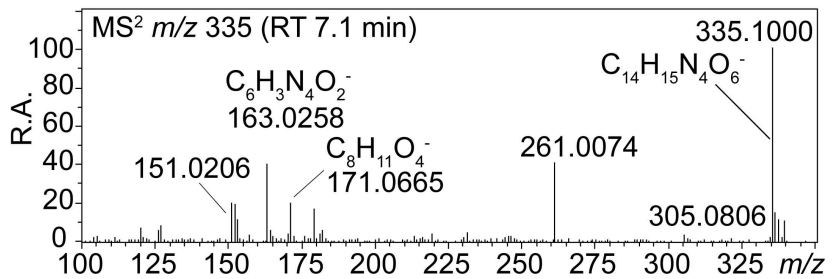

Fig. 5. High-resolution $\mathrm{MS}^{2}$ data for the $m / z 335$ compound.

derivatised with DNPH and acetic acid, and no further sample purification was performed to ensure that sufficient material mass was available for the $\mathrm{MS}^{3}$ experiments. It is noted that in the LC/(-)ESI-ITMS analysis, with its different analytical conditions, more $m / z 335$ isobaric isomer peaks were detected in comparison to the UPLC/(-)ESI-IMS-TOFMS analysis (Fig. S1). The peak with the $R T 27.2$ min was detected from all the investigated filter samples, including the chamber aerosol from campholenic aldehyde, $\alpha$-pinene $/ \mathrm{O}_{3}$, $\alpha$-pinene oxide $/ \mathrm{O}_{3} /$ acidic seed and an ambient filter sample (K-puszta). Almost identical MS ${ }^{2}$ and $\mathrm{MS}^{3}$ patterns were observed for this peak (Fig. 6), demonstrating that the same $\mathrm{m} / \mathrm{z} 335$ compound is present in all of the filter samples and also has atmospheric relevance.

In comparison to the obtained fragmentation pattern from the high resolution $\mathrm{MS}^{2}$ experiment using the Synapt instrument, slightly different product ions were observed from the ITMS analysis. This can be explained by different operational parameters between the two instruments used for the fragmentation studies.

A diagnostic product ion was $\mathrm{m} / \mathrm{z} 171$ for which the high resolution data suggested an elemental composition of
$\mathrm{C}_{8} \mathrm{H}_{11} \mathrm{O}_{4}$. This specific product ion was observed only from one of the various $\mathrm{m} / \mathrm{z} 335$ isomers in the ITMS analysis with matching retention time and confirmed the presence of the same compound from all of the investigated filter samples. The further fragmentation $(m / z 335 \rightarrow m / z$ 171) showed a strong product ion at $m / z 127$, pointing to a further $\mathrm{CO}_{2}$ loss ( $\left.-44 \mathrm{amu}\right)$. Other product ions $(\mathrm{m} / \mathrm{z}, 153,109$, and 83) showed low abundances but could also be explained. All of the observed product ions showed a pattern that is similar to that reported for terpenylic acid $\left(\mathrm{C}_{8} \mathrm{H}_{12} \mathrm{O}_{4}\right.$, MW 172). As both the elemental composition of the $m / z 171$ product ion from the high resolution $\mathrm{MS}^{2}$ data and the fragmentation pattern from $\mathrm{MS}^{3}$ experiments $(m / z 335 \rightarrow m / z$ 171) matched with reported fragmentation behaviour of terpenylic acid (Yasmeen et al., 2010, 2011), the $\mathrm{m} / z 171$ was attributed to deprotonated terpenylic acid. The proposed fragmentation of the $m / z 335$ compound is shown in Fig. 7 . The formation of deprotonated terpenylic acid represents a quite unusual behaviour and might be explained by an intramolecular transfer of oxygen from the nitro group. The migration of an oxygen atom from the ortho nitro group to the $-\mathrm{CH}=\mathrm{N}-$ substructure, followed by rearrangements, has been known for long from hydrazones and was described for derivatised aromatic and aliphatic aldehydes and ketones (Djerassi and Sample, 1965; Goldsmith and Djerassi, 1966; Kleipool and Heins, 1964; Seibl, 1970; Seibl and Völlmin, 1968). Based on the observed fragmentation in the present study, the $m / z 335$ was assigned as the DNPH derivative of terpenylic aldehyde.

The identification of terpenylic aldehyde is an important finding which enables us to explain a possible pathway leading to terpenylic acid in the atmosphere. Terpenylic acid, which is an abundant BSOA tracer compound, 

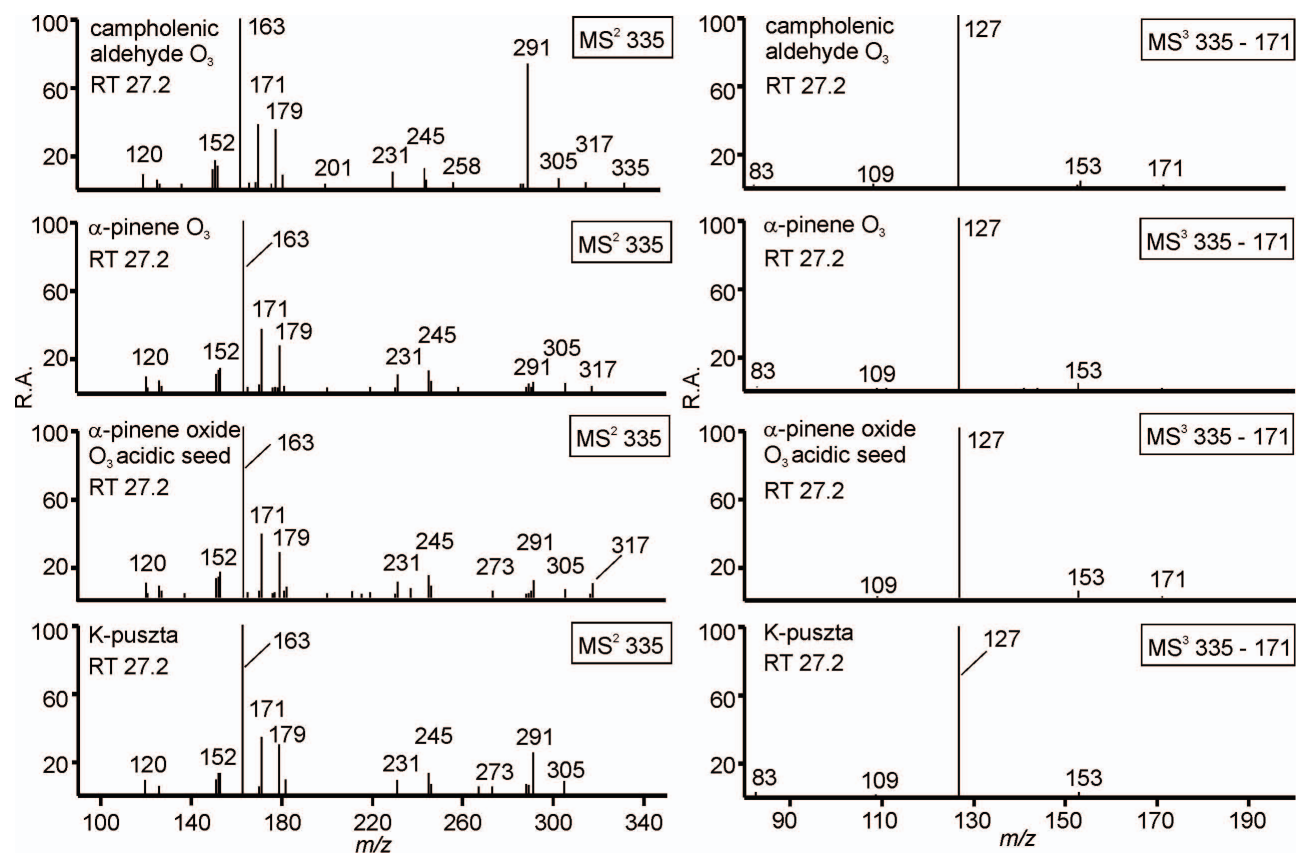

Fig. 6. $\mathrm{MS}^{2}$ and $\mathrm{MS}^{3}$ data for the $m / z 335$ compound from different SOA filter samples and an ambient sample.

is an important early-generation product in $\alpha$-pinene SOA and represents a major monoterpene tracer in atmospheric aerosol (Claeys et al., 2009). Reported concentrations of terpenylic acid are comparable to commonly reported monoterpene oxidation products such as cis-pinic acid and cispinonic acid, ranging up to $20 \mathrm{ng} \mathrm{m}^{-3}$ in $\mathrm{PM}_{10}$ samples (Iinuma and Herrmann, 2013), and significant concentrations also have been reported in $\mathrm{PM}_{2.5}$ (Gómez-González et al., 2012; Kristensen et al., 2013) and $\mathrm{PM}_{1}$ filter samples (Kristensen and Glasius, 2011). In the present study, a precursor of terpenylic acid could be characterised on the basis of mass spectrometric data, which previously had only been proposed in the literature (Claeys et al., 2009). As the aldehydic precursor of terpenylic acid was observed from filter samples of campholenic aldehyde $/ \mathrm{O}_{3}, \alpha$-pinene $/ \mathrm{O}_{3}, \alpha$-pinene oxide/ $\mathrm{O}_{3} /$ acidic seed, and ambient filter samples (Fig. S1), a reaction pathway suggested in the literature (Claeys et al., 2009; Iinuma et al., 2013), which explains the formation of terpenylic acid from $\alpha$-pinene ozonolysis, could be supported. According to this mechanism, the reaction between $\alpha$-pinene and ozone leads to the formation of $\alpha$-pinene oxide, which can rearrange on acidic seed particles, leading to campholenic aldehyde. As campholenic aldehyde contains a double bond it can react further with ozone to form terpenylic aldehyde, which can be further oxidised in the particle phase to terpenylic acid. This pathway was recently corroborated by laboratory experiments (Iinuma et al., 2013) and additional evidence is provided within the present study.

Terpenylic aldehyde can be regarded as a semi-volatile compound and connects gas- and particle-phase processes to explain certain SOA constituents such as terpenylic acid and related compounds (e.g. DTAA). The applied sampling device in this study was optimised for the collection of carbonyl compounds from the gas phase in chamber studies; it is unlikely that these particulate constituents mainly result from the adsorption of gaseous species on the PTFE filter used. However, as no authentic standard was available for terpenylic aldehyde, its DNPH derivatisation efficiency and possible losses during the sample preparation procedure could not be considered. Based on these uncertainties, it was not quantified from the atmospheric aerosol samples in the present study. Nevertheless, further studies are warranted to shed light on the formation of terpenylic aldehyde in the gas phase, and its subsequent phase transition and the reactions leading to terpenylic acid.

\subsubsection{MW 202 and 216 compounds}

The compounds at $m / z 201$ (MW 202, $\mathrm{C}_{9} \mathrm{H}_{14} \mathrm{O}_{5}$ ) and 215 (MW 216, $\mathrm{C}_{10} \mathrm{H}_{16} \mathrm{O}_{5}$ ) both appeared as a single peak from the campholenic aldehyde SOA sample (Fig. S15 and S17, respectively). Based on possible reaction pathways, their chemical structures were proposed, and taking into account the detailed interpretation of the MS data as well as the detection of corresponding DNPH derivatives, their structures were tentatively identified. These compounds (MW 202 and MW 216) have been reported in the literature from $\alpha$-pinene ozonolysis SOA (Winterhalter et al., 2003; Iinuma et al., 2005; Venkatachari and Hopke, 2008; Camredon et al., 2010; Putman et al., 2012) but only little is known about their structure. Peroxidic substructures have been proposed for these compounds in previous studies; the $m / z 201$ compound was 

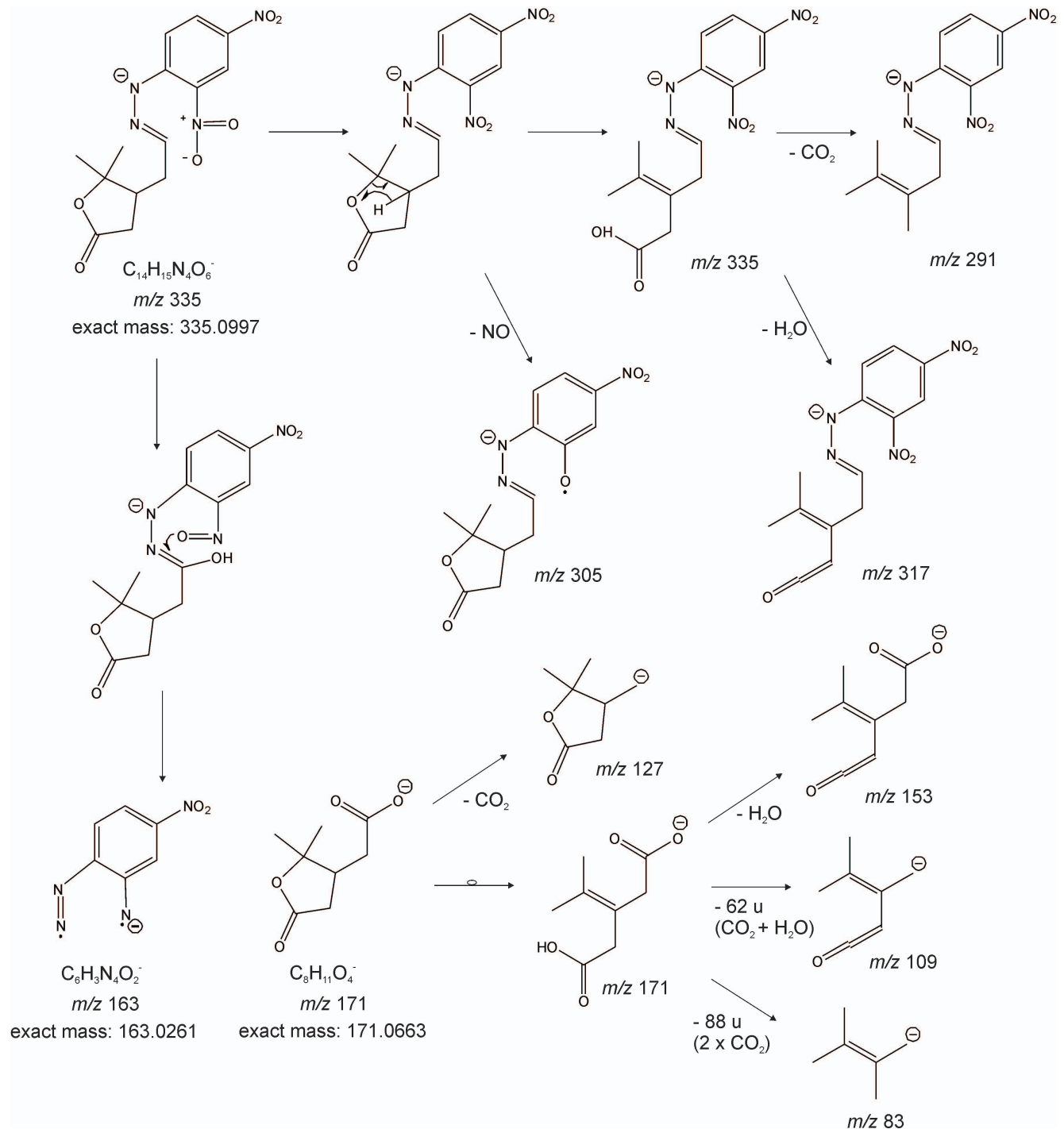

Fig. 7. Proposed fragmentation mechanism for the $m / z 335$ compound showing $\mathrm{MS}^{2}$ and $\mathrm{MS}^{3}(m / z 335 \rightarrow m / z$ 171) product ions.
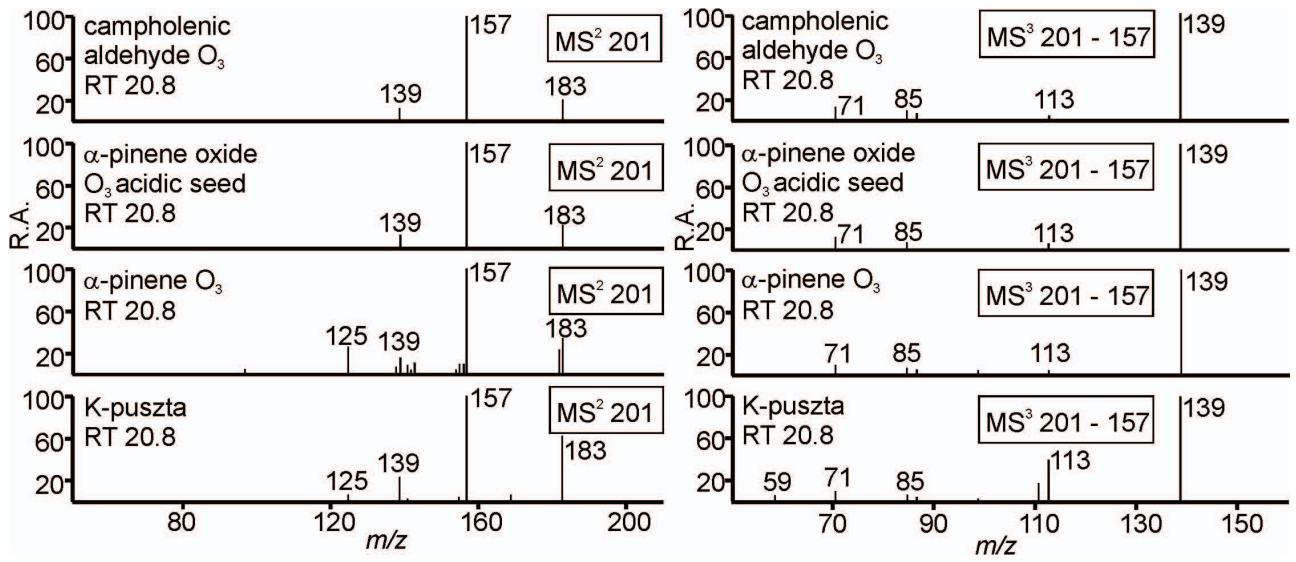

Fig. 8. $\mathrm{MS}^{2}$ and $\mathrm{MS}^{3}$ product ion spectra for the $m / z, 201$ compound. 


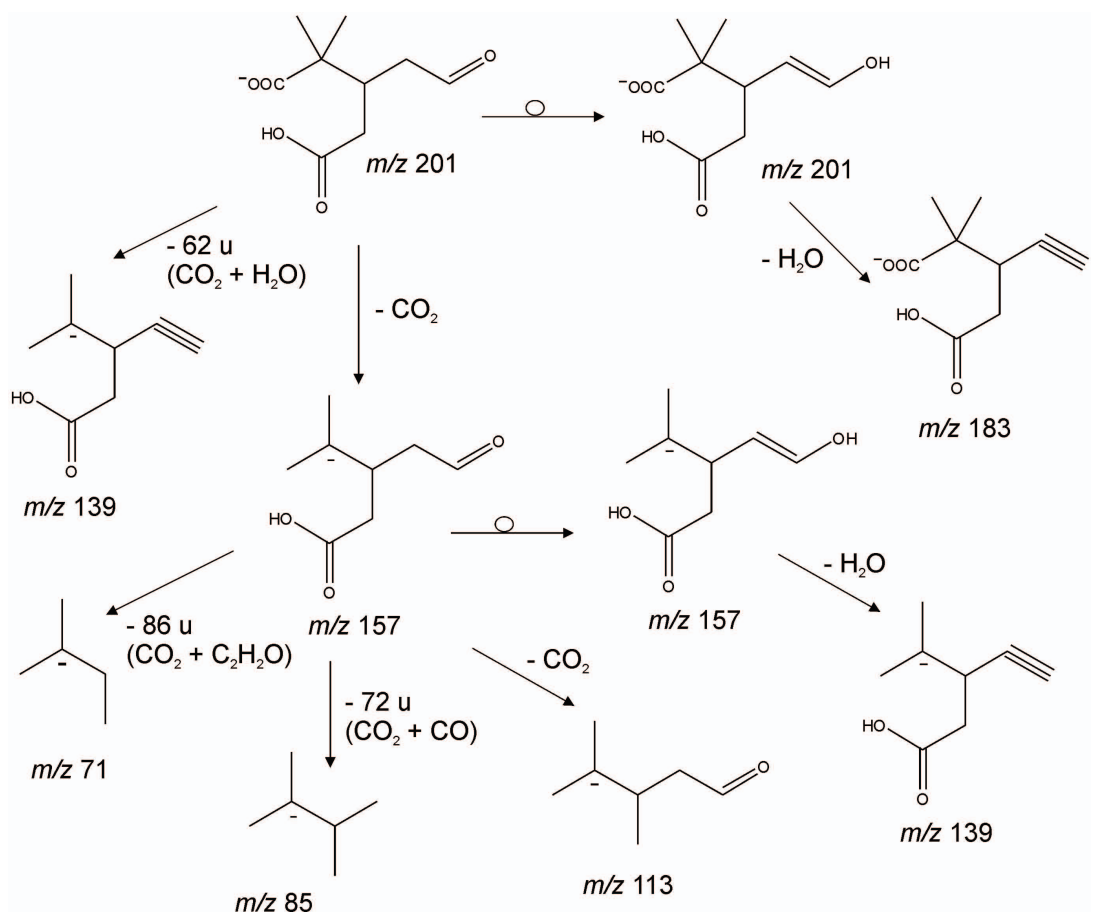

Fig. 9. Proposed structure of the $m / z 201$ compound and its fragmentation mechanism.
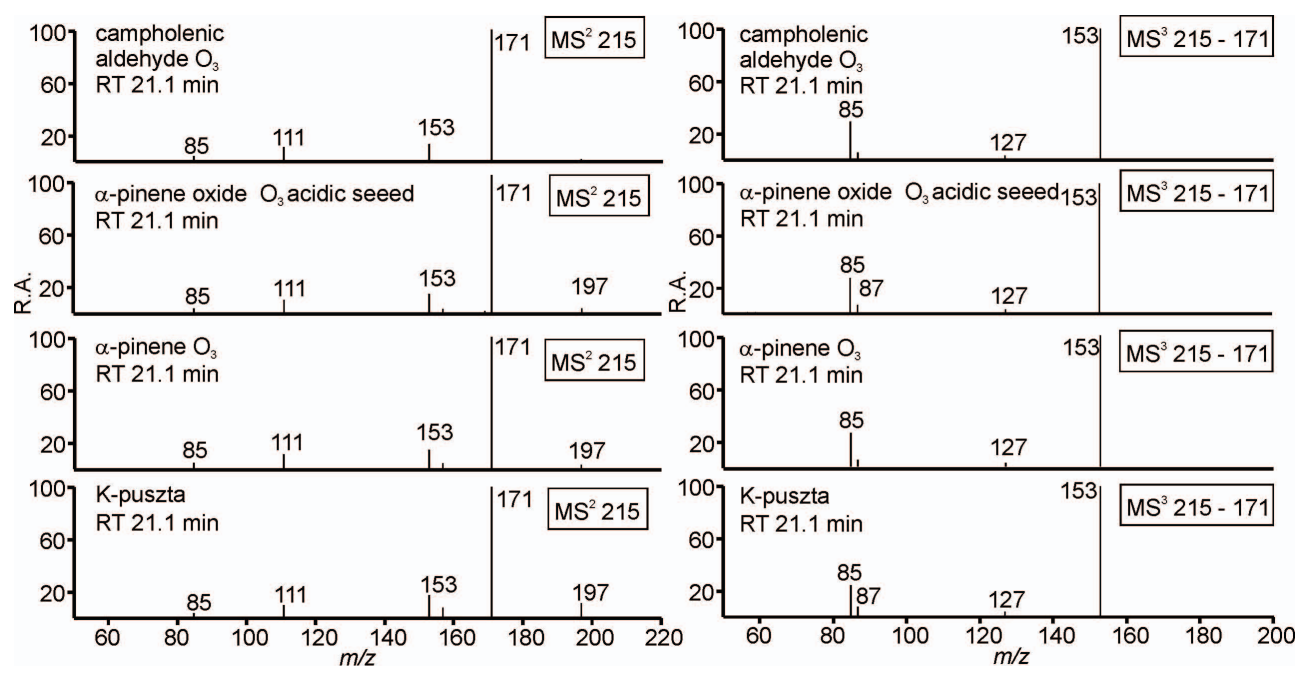

Fig. 10. $\mathrm{MS}^{2}$ and $\mathrm{MS}^{3}$ product ion spectra for the $m / z, 215$ compound.

assigned to peroxo-pinic acid by Winterhalter et al. (2003), whereas a tricarbonyl group-containing hydroperoxide was suggested by Camredon et al. (2010) for the $m / z 215$ compound.

In this study, several isomers were detected in the $\alpha$ pinene $/ \mathrm{O}_{3}$ SOA sample for the $\mathrm{m} / z 201$ compound but only one peak was observed from the campholenic aldehyde ozonolysis (Fig. S15). Based on its fragmentation mechanism, a peroxidic substructure could not be confirmed as the main product ions resulted from the loss of water $(-18 \mathrm{amu})$,
$\mathrm{CO}_{2}(-44 \mathrm{amu})$ and the combination of both $(-62 \mathrm{amu})$, as shown in the $\mathrm{MS}^{2}$ data (Fig. 8, left), whereas the $\mathrm{MS}^{3}$ $(m / z 201 \rightarrow m / z$ 157) spectrum was dominated by the loss of water (Fig. 8, right). These product ions can be explained with a mono-aldehydic dicarboxylic acid structure, as shown in Fig. 9. The corresponding mono-DNPH derivative of the MW 202 compound $(m / z$ 381) together with its resulting MS data are given in Fig. S16.

For the $m / z 215$ compound, several isomers were also detected from the $\alpha$-pinene ozonolysis and the ambient SOA 


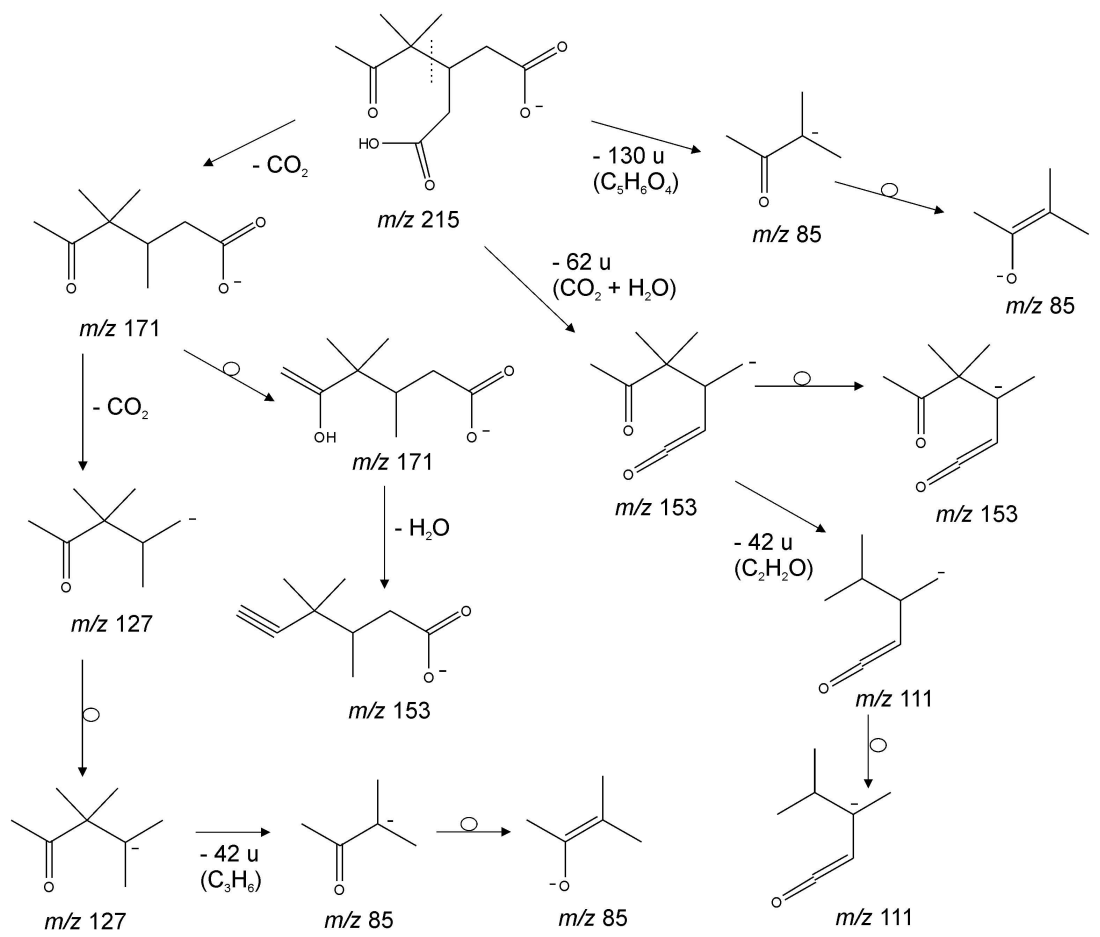

Fig. 11. Proposed structure of the $m / z 215$ compound and its fragmentation mechanism.

sample but the compound eluting at 21.1 min could be clearly associated with a campholenic aldehyde oxidation product (Fig. S17). Based on the $\mathrm{MS}^{2}$ and $\mathrm{MS}^{3}$ product ion spectra (Fig. 10), a mono-carbonyl group-containing dicarboxylic acid and its fragmentation mechanism could be proposed (Fig. 11). Similarly, for the MW 216 compound a corresponding mono-DNPH derivative $(m / z$ 395) was detected; its fragmentation behaviour is given in Fig. S18.

The current study enabled the identification of campholenic aldehyde as a possible precursor compound for specific biogenic aerosol constituents, which are commonly observed in ambient aerosol. Other, yet unknown formation routes or pathways that could be favoured under chamber conditions can explain the observed differences in abundances for some of the oxidation products detected in the atmospheric and the chamber SOA samples.

\section{Conclusions and atmospheric implications}

The present study demonstrates that the ozonolysis of campholenic aldehyde leads to highly functionalised oxidation products, which are responsible for its high SOA formation potential. These highly functionalised compounds explain the enhanced degree of functionality of organic aerosol constituents and the oxidation state of atmospheric aerosol, which usually cannot be reached under normal aerosol chamber experimental conditions.
Campholenic aldehyde was shown to be a possible precursor compound for important aerosol constituents commonly observed in ambient aerosol samples. These oxidation products include terpenylic acid and DTAA, and a suggested pathway reported in the literature could be confirmed. Furthermore, the direct precursor of terpenylic acid, i.e. terpenylic aldehyde $\left(\mathrm{C}_{8} \mathrm{H}_{12} \mathrm{O}_{3}\right)$, could be identified and was characterised by detailed interpretation of its mass spectral data. Among other highly oxidised particle-phase products, information about the structures of the MW $202\left(\mathrm{C}_{9} \mathrm{H}_{14} \mathrm{O}_{5}\right)$ and MW $216\left(\mathrm{C}_{10} \mathrm{H}_{16} \mathrm{O}_{5}\right)$ compounds was obtained from detailed $\mathrm{MS}^{2}$ and $\mathrm{MS}^{3}$ experiments. As these compounds were demonstrated to be of atmospheric relevance, their structures were characterised as carbonyl-dicarboxylic acids based on their mass spectral fragmentation patterns and those of corresponding DNPH derivatives. Their formation from campholenic aldehyde oxidation highlights the importance of campholenic aldehyde as an intermediate and could be used to explain $\alpha$-pinene SOA products, whose structures do not retain an $\alpha$-pinene or cyclobutane skeleton.

\section{Supplementary material related to this article is available online at http://www.atmos-chem-phys.net/14/ 719/2014/acp-14-719-2014-supplement.pdf.}


Acknowledgements. Research at TROPOS and the University of Antwerp was supported by the Belgian Federal Science Policy Office through the network project "Biogenic Influence on Oxidants and Secondary Organic Aerosol: theoretical, laboratory and modelling investigations (BIOSOA)". Research at TROPOS was also supported by the European Commission through the EUROCHAMP-2 project (228335), whereas research at the University of Antwerp was supported by the Research Foundation - Flanders (FWO).

Edited by: J. B. Burkholder

\section{References}

Ali, N. A. A., Wurster, M., Arnold, N., Teichert, A., Schmidt, J., Lindequist, U., and Wessjohann, L.: Chemical composition and biological activities of essential oils from the oleogum resins of three endemic Soqotraen Boswellia species, Rec. Nat. Prod., 2, 6-12, 2008

Alvarado, A., Tuazon, E. C., Aschmann, S. M., Atkinson, R., and Arey, J.: Products of the gas-phase reactions of $\mathrm{O}\left({ }^{3} \mathrm{P}\right)$ atoms and $\mathrm{O}_{3}$ with $\alpha$-pinene and 1,2-dimethyl-1-cyclohexene, J. Geophys. Res.-Atmos., 103, 25541-25551, 1998.

Amin, H. S., Hatfield, M. L., and Hartz, K. E. H.: Characterisation of secondary organic aerosol generated from ozonolysis of $\alpha$ pinene mixtures, Atmos. Environ., 67, 323-330, 2013.

Anttila, P., Rissanen, T., Shimmo, M., Kallio, M., Hyötyläinen, T., Kulmala, M., and Riekkola, M. L.: Organic compounds in atmospheric aerosols from a Finnish coniferous forest, Boreal Environ. Res., 10, 371-384, 2005.

Berndt, T. and Böge, O.: Products and mechanism of the gas-phase reaction of $\mathrm{NO}_{3}$ radicals with $\alpha$-pinene, J. Chem. Soc. Faraday Trans., 93, 3021-3027, 1997.

Birch, M. E. and Cary, R. A.: Elemental carbon-based method for monitoring occupational exposures to particulate diesel exhaust, Aerosol Sci. Tech., 25, 221-241, 1996.

Bleier, D. B. and Elrod, M. J.: Kinetics and thermodynamics of atmospherically relevant aqueous phase reactions of $\alpha$-pinene oxide, J. Phys. Chem. A, 117, 4223-4232, 2013.

Brombacher, S., Oehme, M., and Beukes, J. A.: HPLC combined with multiple mass spectrometry $\left(\mathrm{MS}^{n}\right)$ : an alternative for the structure elucidation of compounds and artefacts found in smog chamber samples, J. Environ. Monitor., 3, 311-316, 2001.

Camredon, M., Hamilton, J. F., Alam, M. S., Wyche, K. P., Carr, T., White, I. R., Monks, P. S., Rickard, A. R., and Bloss, W. J.: Distribution of gaseous and particulate organic composition during dark $\alpha$-pinene ozonolysis, Atmos. Chem. Phys., 10, 2893-2917, doi:10.5194/acp-10-2893-2010, 2010.

Castro, J. M., Linares-Palomino, P. J., Salido, S., Altarejos, J., Nogueras, M., and Sánchez, A.: Enantiospecific synthesis, separation and olfactory evaluation of all diastereomers of a homologue of the sandalwood odorant Polysantol ${ }^{\circledR}$, Tetrahedron, 61, 11192-11203, 2005.

Claeys, M., Iinuma, Y., Szmigielski, R., Surratt, J. D., Blockhuys, F., Van Alsenoy, C., Böge, O., Sierau, B., Gómez-González, Y., Vermeylen, R., Van der Veken, P., Shahgholi, M., Chan, A. W. H., Herrmann, H., Seinfeld, J. H., and Maenhaut, W.: Terpenylic acid and related compounds from the oxidation of $\alpha$-pinene: im- plications for new particle formation and growth above forests, Environ. Sci. Technol., 43, 6976-6982, 2009.

Clegg, S. L., Brimblecombe, P., and Wexler, A. S.: Thermodynamic model of the system $\mathrm{H}^{+}-\mathrm{NH}_{4}^{+}-\mathrm{SO}_{4}^{2-}-\mathrm{NO}_{3}^{-}-\mathrm{H}_{2} \mathrm{O}$ at tropospheric temperatures, J. Phys. Chem. A, 102, 2137-2154, 1998.

Cocker, D. R., Clegg, S. L., Flagan, R. C., and Seinfeld, J. H.: The effect of water on gas-particle partitioning of secondary organic aerosol. Part I: $\alpha$-pinene/ozone system, Atmos. Environ., 35, 6049-6072, 2001

Djerassi, C. and Sample, S. D.: Mass spectrometric fragmentation of nitrophenylhydrazones, Nature, 208, 1314, doi:10.1038/2081314a0, 1965.

Gogus, F., Ozel, M. Z., and Lewis, A. C.: Extraction of essential oils of leaves and flowers of Achillea monocephala by superheated water, Flavour Frag. J., 21, 122-128, 2006.

Goldsmith, D. and Djerassi, C.: Mass spectrometry in structural and stereochemical problems. CXIII. Specific hydrogen rearrangements in the fragmentations of hydrazones, J. Org. Chem., 31, 3661-3666, 1966.

Gómez-González, Y., Wang, W., Vermeylen, R., Chi, X., Neirynck, J., Janssens, I. A., Maenhaut, W., and Claeys, M.: Chemical characterisation of atmospheric aerosols during a 2007 summer field campaign at Brasschaat, Belgium: sources and source processes of biogenic secondary organic aerosol, Atmos. Chem. Phys., 12, 125-138, doi:10.5194/acp-12-125-2012, 2012.

Griffin, R. J., Cocker, D. R., Flagan, R. C., and Seinfeld, J. H.: Organic aerosol formation from the oxidation of biogenic hydrocarbons, J. Geophys. Res.-Atmos., 104, 3555-3567, 1999.

Hallquist, M., Wenger, J. C., Baltensperger, U., Rudich, Y., Simpson, D., Claeys, M., Dommen, J., Donahue, N. M., George, C., Goldstein, A. H., Hamilton, J. F., Herrmann, H., Hoffmann, T., Iinuma, Y., Jang, M., Jenkin, M. E., Jimenez, J. L., Kiendler-Scharr, A., Maenhaut, W., McFiggans, G., Mentel, Th. F., Monod, A., Prévôt, A. S. H., Seinfeld, J. H., Surratt, J. D., Szmigielski, R., Wildt, J.: The formation, properties and impact of secondary organic aerosol: current and emerging issues, Atmos. Chem. Phys., 9, 5155-5236, doi:10.5194/acp-9-5155-2009, 2009.

Hao, L. Q., Romakkaniemi, S., Yli-Pirilä, P., Joutsensaari, J., Kortelainen, A., Kroll, J. H., Miettinen, P., Vaattovaara, P., Tiitta, P., Jaatinen, A., Kajos, M. K., Holopainen, J. K., Heijari, J., Rinne, J., Kulmala, M., Worsnop, D. R., Smith, J. N., and Laaksonen, A.: Mass yields of secondary organic aerosols from the oxidation of $\alpha$-pinene and real plant emissions, Atmos. Chem. Phys., 11, 1367-1378, doi:10.5194/acp-11-1367-2011, 2011.

Hatfield, M. L. and Hartz, K. E. H.: Secondary organic aerosol from biogenic volatile organic compound mixtures, Atmos. Environ., 45, 2211-2219, 2011.

Hellén, H., Hakola, H., Reissell, A., and Ruuskanen, T. M.: Carbonyl compounds in boreal coniferous forest air in Hyytiälä, Southern Finland, Atmos. Chem. Phys., 4, 1771-1780, doi:10.5194/acp-4-1771-2004, 2004.

Henry, K. M. and Donahue, N. M.: Effect of the $\mathrm{OH}$ radical scavenger hydrogen peroxide on secondary organic aerosol formation from $\alpha$-pinene ozonolysis, Aerosol Sci. Tech., 45, 696-700, 2011.

Hoffmann, T., Odum, J. R., Bowman, F., Collins, D., Klockow, D., Flagan, R. C., and Seinfeld, J. H.: Formation of organic aerosols 
from the oxidation of biogenic hydrocarbons, J. Atmos. Chem., 26, 189-222, 1997.

Iinuma, Y. and Herrmann, H.: Nitro- and nitro-oxy-compounds in multiphase particle chemistry: field and analytical studies, in: role of oxides and acids of nitrogen in atmospheric chemistry, NATO Science for Peace and Security Series - C, Environmental Security, edited by: Barnes, I., and Rudziński, K. J., Springer, Dordrecht, The Netherlands, 185-193, 2013.

Iinuma, Y., Böge, O., Miao, Y., Sierau, B., Gnauk, T., and Herrmann, H.: Laboratory studies on secondary organic aerosol formation from terpenes, Faraday Discuss., 130, 279-294, 2005.

Iinuma, Y., Böge, O., Keywood, M., Gnauk, T., and Herrmann, H.: Diaterebic acid acetate and diaterpenylic acid acetate: atmospheric tracers for secondary organic aerosol formation from 1,8cineol oxidation, Environ. Sci. Technol., 43, 280-285, 2009a.

Iinuma, Y., Böge, O., Kahnt, A., Herrmann, H.: Laboratory chamber studies on the formation of organosulfates from reactive uptake of monoterpene oxides, Phys. Chem. Chem. Phys., 11, 79857997, 2009b.

Iinuma, Y., Kahnt, A., Mutzel, A., Böge, O., and Herrmann, H.: Ozone-driven secondary organic aerosol production chain, Environ. Sci. Technol., 47, 3639-3647, 2013.

Jaoui, M. and Kamens, R. M.: Gaseous and particulate oxidation products analysis of a mixture of $\alpha$-pinene plus $\beta$-pinene $/ \mathrm{O}_{3} /$ air in the absence of light and $\alpha$-pinene plus $\beta$-pinene/ $\mathrm{NO}_{\mathrm{x}} /$ air in the presence of natural sunlight, J. Atmos. Chem., 44, 259-297, 2003.

Kahnt, A., Iinuma, Y., Böge, O., Mutzel, A., and Herrmann, H.: Denuder sampling techniques for the determination of gas-phase carbonyl compounds: a comparison and characterisation of in situ and ex situ derivatisation methods, J. Chromatogr. B, 879, 1402-1411, 2011.

Kallio, M., Jussila, M., Rissanen, T., Anttila, P., Hartonen, K., Reissell, A., Vreuls, R., Adahchour, M., and Hyötyläinen, T.: Comprehensive two-dimensional gas chromatography coupled to time-of-flight mass spectrometry in the identification of organic compounds in atmospheric aerosols from coniferous forest, J. Chromatogr. A, 1125, 234-243, 2006.

Kleipool, R. J. C. and Heins, J. Th.: Mass-spectrometric identification of organic derivatives, Nature, 203, 1280, doi:10.1038/2031280a0, 1964.

Kölliker, S., Oehme, M., and Merz, L.: Unusual MS ${ }^{n}$ fragmentation patterns of 2,4-dinitrophenylhydrazine and its propanone derivative, Rapid Commun. Mass Spectrom., 15, 2117-2126, 2001.

Kristensen, K. and Glasius, M.: Organosulfates and oxidation products from biogenic hydrocarbons in fine aerosols from a forest in North West Europe during spring, Atmos. Environ., 45, 45464556, 2011.

Kristensen, K., Enggrob, K. L., King, S. M., Worton, D. R., Platt, S. M., Mortensen, R., Rosenoern, T., Surratt, J. D., Bilde, M., Goldstein, A. H., and Glasius, M.: Formation and occurrence of dimer esters of pinene oxidation products in atmospheric aerosols, Atmos. Chem. Phys., 13, 3763-3776, doi:10.5194/acp-13-37632013, 2013.

Maenhaut, W., Raes, N., Chi, X., Cafmeyer, J., and Wang, W.: Chemical composition and mass closure for $\mathrm{PM}_{2.5}$ and $\mathrm{PM}_{10}$ aerosol at K-puszta, Hungary, in summer 2006, X-Ray Spectrom., 37, 193-197, 2008.
Na, K., Song, C., Switzer, C., and Cocker, D. R.: Effect of ammonia on secondary organic aerosol formation from $\alpha$-pinene ozonolysis in dry and humid conditions, Environ. Sci. Technol., 41, 6096-6102, 2007.

Ng, N. L., Kroll, J. H., Keywood, M. D., Bahreini, R., Varutbangkul, V., Flagan, R. C., Seinfeld, J. H., Lee, A., and Goldstein, A. H.: Contribution of first- versus second-generation products to secondary organic aerosols formed in the oxidation of biogenic hydrocarbons, Environ. Sci. Technol., 40, 2283-2297, 2006.

Nölscher, A. C., Williams, J., Sinha, V., Custer, T., Song, W., Johnson, A. M., Axinte, R., Bozem, H., Fischer, H., Pouvesle, N., Phillips, G., Crowley, J. N., Rantala, P., Rinne, J., Kulmala, M., Gonzales, D., Valverde-Canossa, J., Vogel, A., Hoffmann, T., Ouwersloot, H. G., Vilà-Guerau de Arellano, J. V. G., and Lelieveld, J.: Summertime total $\mathrm{OH}$ reactivity measurements from boreal forest during HUMPPA-COPEC 2010, Atmos. Chem. Phys., 12, 8257-8270, doi:10.5194/acp-12-82572012, 2012.

Pathak, R. K., Stanier, C. O., Donahue, N. M., and Pandis, S. N.: Ozonolysis of $\alpha$-pinene at atmospherically relevant concentrations: temperature dependence of aerosol mass fractions (yields), J. Geophys. Res.-Atmos., 112, D03201, doi:10.1029/2006JD007436, 2007.

Pio, C., Alves, C., and Duarte, A.: Organic components of aerosols in a forested area of central Greece, Atmos. Environ., 35, 389401, 2001.

Presto, A. A. and Donahue, N. M.: Investigation of $\alpha$-pinene plus ozone secondary organic aerosol formation at low total aerosol mass, Environ. Sci. Technol., 40, 3536-3543, 2006.

Putman, A. L., Offenberg, J. H., Fisseha, R., Kundu, S., Rahn, T. A., and Mazzoleni, L. R.: Ultrahigh-resolution FT-ICR mass spectrometry characterisation of $\alpha$-pinene ozonolysis SOA, Atmos. Environ., 46, 164-172, 2012.

Saathoff, H., Naumann, K.-H., Möhler, O., Jonsson, Å. M., Hallquist, M., Kiendler-Scharr, A., Mentel, Th. F., Tillmann, R., and Schurath, U.: Temperature dependence of yields of secondary organic aerosols from the ozonolysis of $\alpha$-pinene and limonene, Atmos. Chem. Phys., 9, 1551-1577, doi:10.5194/acp-9-15512009, 2009.

Samaneh, E. T., Tayebeh, R., Hassan, E., and Vahid, N.: Composition of essential oils in subterranean organs of three species of Valeriana L., Nat. Prod. Res., 24, 1834-1842, 2010.

Schrader W., Geiger, J., Hoffmann, T., Klockow, D., and Korte, E.-H.: Application of gas chromatographycryocondensation-Fourier transform infrared spectroscopy and gas chromatography-mass spectrometry to the identification of gas phase reaction products from the $\alpha$-pinene/ozone reaction, J. Chromatogr. A, 864, 299-314, 1999.

Seibl, J.: Zur Massenspektrometrie von Nitrophenylverbindungen - II. Nitrophenylhydrazone aliphatischer Aldehyde und Ketone, Org. Mass Spectrom., 3, 417-432, 1970.

Seibl, J. and Völlmin, J.: Zur Massenspektrometrie von Nitrophenylverbindungen - I. Nitrophenylhydrazone aromatischer Aldehyde und Ketone und verwandte Verbindungen, Org. Mass Spectrom., 1, 713-737, 1968.

Shilling, J. E., Chen, Q., King, S. M., Rosenoern, T., Kroll, J. H., Worsnop, D. R., McKinney, K. A., and Martin, S. T.: Particle mass yield in secondary organic aerosol formed by the dark 
ozonolysis of $\alpha$-pinene, Atmos. Chem. Phys., 8, 2073-2088, doi:10.5194/acp-8-2073-2008, 2008.

Sinha, V., Williams, J., Lelieveld, J., Ruuskanen, T. M., Kajos, M. K., Patokoski, J., Hellén, H., Hakola, H., Mogensen, D., Boy, M., Rinne, J., and Kulmala, M.: OH reactivity measurements within a boreal forest: evidence for unknown reactive emissions, Environ. Sci. Technol., 44, 6614-6620, 2010.

Song, C., Zaveri, R. A., Alexander, M. L., Thornton, J. A., Madronich, S., Ortega, J. V., Zelenyuk, A., Yu, X. Y., Laskin, A., and Maughan, D. A.: Effect of hydrophobic primary organic aerosols on secondary organic aerosol formation from ozonolysis of $\alpha$-pinene, Geophys. Res. Lett., 34, L20803 doi:10.1029/2007GL030720, 2007.

Van den Bergh, V., Vanhees, I., De Boer, R., Compernolle, F., and Vinckier, C.: Identification of the oxidation products of the reaction between $\alpha$-pinene and hydroxyl radicals by gas and high performance liquid chromatography with mass spectrometric detection, J. Chromatogr. A, 896, 135-148, 2000.

Van den Bergh, V., Coeckelberghs, H., Vankerckhoven, H., Compernolle, F., and Vinckier, C.: Study of the carbonyl products of terpene/OH radical reactions: detection of the 2,4-DNPH derivatives by HPLC-MS, Anal. Bioanal. Chem., 379, 484-494, 2004.

Venkatachari, P. and Hopke, P. K.: Characterisation of products formed in the reaction of ozone with $\alpha$-pinene: case for organic peroxides, J. Environ. Monitor., 10, 966-974, 2008.

Weissbecker, B., Holighaus, G., and Schütz, S.: Gas chromatography with mass spectrometric and electroantennographic detection: analysis of wood odorants by direct coupling of insect olfaction and mass spectrometry, J. Chromatogr. A, 1056, 209-216, 2004.
Winterhalter, R., Van Dingenen, R., Larsen, B. R., Jensen, N. R., and Hjorth, J.: LC-MS analysis of aerosol particles from the oxidation of $\alpha$-pinene by ozone and OH-radicals, Atmos. Chem. Phys. Discuss., 3, 1-39, doi:10.5194/acpd-3-1-2003, 2003.

Wolfe, G. M., Thornton, J. A., McKay, M., and Goldstein, A. H.: Forest-atmosphere exchange of ozone: sensitivity to very reactive biogenic VOC emissions and implications for incanopy photochemistry, Atmos. Chem. Phys., 11, 7875-7891, doi:10.5194/acp-11-7875-2011, 2011.

Yasmeen, F., Vermeylen, R., Szmigielski, R., Iinuma, Y., Böge, O., Herrmann, H., Maenhaut, W., and Claeys, M.: Terpenylic acid and related compounds: precursors for dimers in secondary organic aerosol from the ozonolysis of $\alpha$ - and $\beta$-pinene, Atmos. Chem. Phys., 10, 9383-9392, doi:10.5194/acp-10-9383-2010, 2010.

Yasmeen, F., Szmigielski, R., Vermeylen, R., Gómez-González, Y., Surratt, J. D., Chan, A. W. H., Seinfeld, J. H., Maenhaut, W., and Claeys, M.: Mass spectrometric characterization of isomeric terpenoic acids from the oxidation of $\alpha$-pinene, $\beta$-pinene, $d$ limonene, and $\Delta^{3}$-carene in fine forest aerosol, J. Mass Spectrom., 46, 425-442, 2011.

Yu, J. Z., Cocker, D. R., Griffin, R. J., Flagan, R. C., Seinfeld, J. H.: Gas-phase ozone oxidation of monoterpenes: gaseous and particulate products, J. Atmos. Chem., 34, 207-258, 1999. 